\title{
Reframing Financing and Investment for a Sustainable Ocean Economy
}

POLICY PERSPECTIVES

OECD ENVIRONMENT POLICY PAPER NO. 22
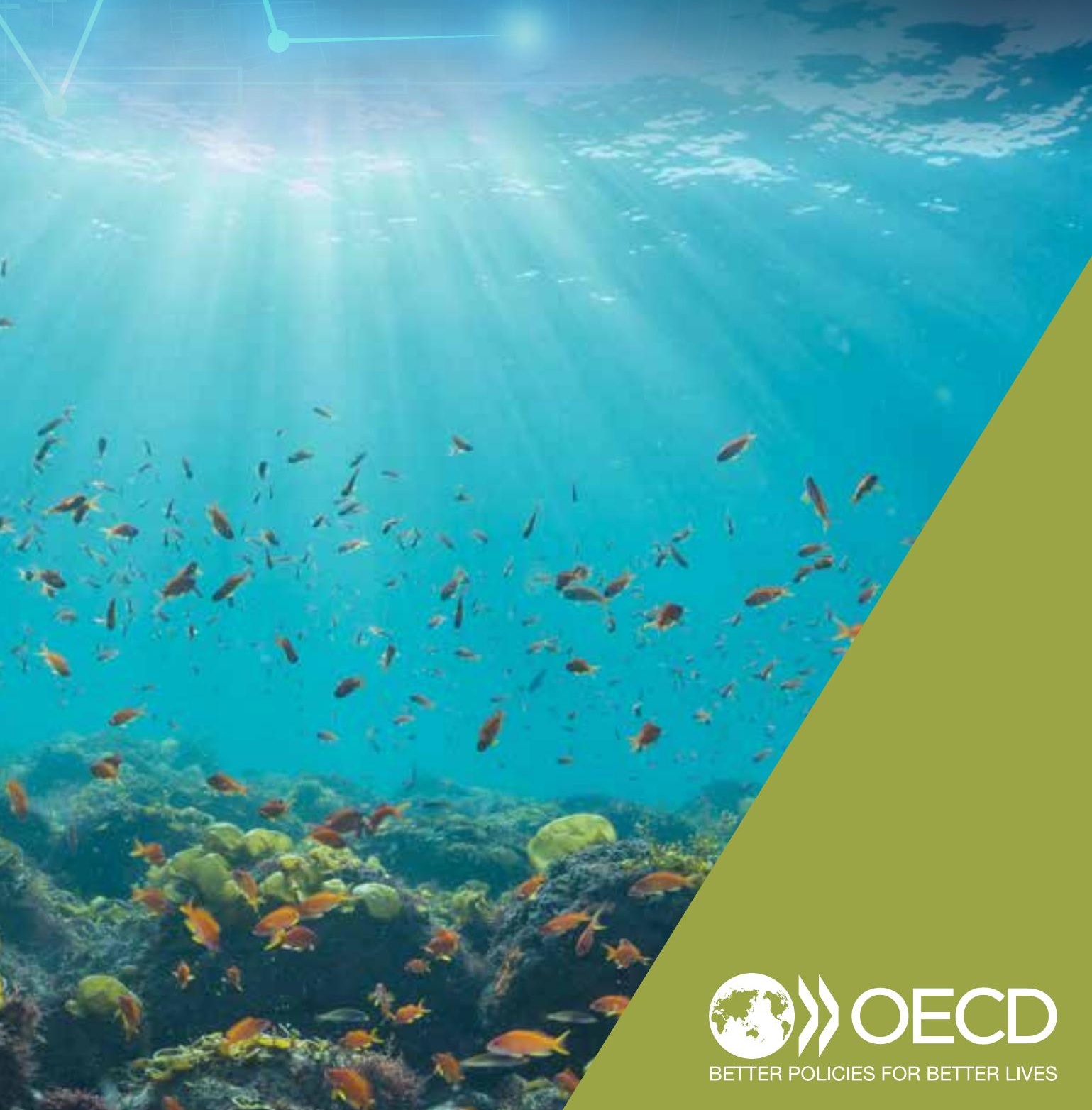


\section{Disclaimers}

This paper is published under the responsibility of the Secretary-General of the OECD. The opinions expressed and the arguments employed herein do not necessarily reflect the official views of OECD member countries. This document and any map included herein are without prejudice to the status of or sovereignty over any territory, to the delimitation of international frontiers and boundaries and to the name of any territory, city or area. For Israel, change is measured between 1997-99 and 2009-11. The statistical data for Israel are supplied by and under the responsibility of the relevant Israeli authorities. The use of such data by the OECD is without prejudice to the status of the Golan Heights, East Jerusalem and Israeli settlements in the West Bank under the terms of international law.

\section{Copyright}

You can copy, download or print OECD content for your own use, and you can include excerpts from OECD publications, databases and multimedia products in your own documents, presentations, blogs, websites and teaching materials, provided that suitable acknowledgment of OECD as source and copyright owner is given. All requests for public or commercial use and translation rights should be submitted to rights@oecd.org. Requests for permission to photocopy portions of this material for public or commercial use shall be addressed directly to the Copyright Clearance Center (CCC) at info@copyright.com or the Centre français d'exploitation du droit de copie (CFC) at contact@cfcopies.com.

\section{(c) OECD 2020}

\section{ISSN 2309-7841}

Authorised for publication by Rodolfo Lacy, Director, Environment Directorate

\section{Acknowledgements}

This publication was prepared by the OECD Environment Directorate. The authors are Andrew Prag and Kate Kooka of the Environment Directorate, and Piera Tortora of the Development Co-operation Directorate, under the guidance of Anthony Cox, Deputy Director of the Environment Directorate. The authors would like to thank the following OECD colleagues for their useful comments and suggestions during the drafting of this publication: Geraldine Ang, Katia Karousakis, Mireille Martini and Edward Perry (Environment Directorate); Valentina Bellesi and Priscilla Boiardi (Development Co-operation Directorate); Claire Jolly (Science, Technology and Innovation Directorate); and Claire Delpeuch and Will Symes (Fisheries and Agriculture Directorate). Jeong-won Cho of the Environment Directorate provided administrative support in the preparation of this publication, and Elizabeth Del Bourgo and Stéphanie Simonin-Edwards provided communications support.

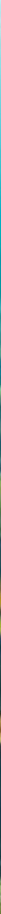



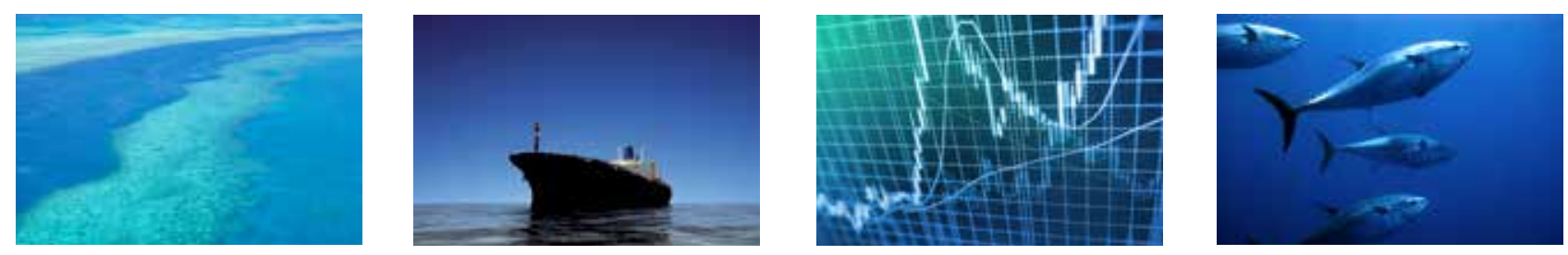

\section{Contents}

Executive Summary $\quad 3$

$\begin{array}{ll}\text { Introduction } & 6\end{array}$

Defining and financing a sustainable ocean economy 7

What is the ocean economy and what makes it "sustainable"?

What are the key challenges in scaling up sustainable ocean finance and investment? 11

What can sustainable ocean finance learn from climate finance and investment? 14

Mobilising ocean finance: capital, policies and investment models 18

Types and sources of capital relevant to ocean finance 18

Policy and regulatory frameworks for scaling-up sustainable ocean finance 19

Financing instruments and investment models 26

Conclusions 33

$\begin{array}{ll}\text { References } & 35\end{array}$ 


\section{Reframing Financing and Investment for a Sustainable Ocean Economy}




\section{Executive Summary}

The ocean is essential for human well-being, but it is increasingly under threat. As well as providing food and livelihoods to billions of people, a healthy ocean is critical to the well-being of the planet itself. The ocean serves to regulate the Earth's climate system and is a vast reservoir of biodiversity, thus providing multiple and invaluable ecosystem services such as protection against storms. Yet despite its size and importance, the potential for the ocean to continue to underpin livelihoods and economic activity is jeopardised by increasing pressures due to human activity. These pressures are numerous but include overfishing and other marine resource over-exploitation, the deluge of plastic and other pollution, habitat degradation, and climate change impacts such as ocean acidification.

As the world reels from COVID-19, governments have a key opportunity to use stimulus packages as a means to reduce pressures on ocean ecosystems. Those pressures intensified rapidly in recent years; before the COVID-19 pandemic the global ocean economy was growing faster than the rest of the economy. The crisis resulting from the pandemic has had severe economic and social impacts on several ocean sectors. The speed and nature of the economic recovery will have important implications not only for jobs and livelihoods but also for the sustainability of ocean activities - and consequentially on the state of ocean health in the coming years.

The ocean economy is large, diverse and set to grow again after the crisis, but without policy action growth is likely to contribute further to over-exploitation and pollution, with sustainable investment opportunities being missed. Established ocean sectors command substantial capital flows from both public and private sources, but current policies and incentives mean that the most financially attractive investments are usually not the most sustainable. As more financial capital enters ocean-based industries, it will be critical that policy acts to steer investment towards improved sustainability, thus exploiting the substantial opportunities that more sustainable activities represent.

The diversity of ocean economic sectors - and of their impacts on the ocean - means that there are many different dimensions of ocean sustainability. Synergies and tradeoffs exist between these dimensions, for example where off-shore renewable energy reduces emissions but may negatively impact ocean ecosystems. Despite this diversity, some common financing challenges exist, such as that economic returns do not sufficiently account for environmental impacts, and that the benefits provided by the ocean's natural environment both now and in the future are not sufficiently valued. Additionally, the characteristics of the ocean environment have an important bearing on reorienting financing to more sustainable activities, for example through difficulties to define and enforce access and property rights - notably in international waters - and because many economic assets are invisible or hard to observe.

To help focus policymaking in ways that can shift the balance towards sustainable practices across ocean activities, it is useful to reframe the ocean economy by distinguishing sectors according to their relative dependence on ocean ecosystems:

- Sectors that are economically dependent on ocean natural capital, such as wildcapture fisheries, require policies and financing instruments that capture the future value of that natural capital, combined with clear regulation and enforcement. 
- Sectors that are physically located in the ocean but not dependent on natural capital, such as energy and shipping, require different policies focused more on accounting for ocean environmental impacts and damages.

- Sectors located outside of the ocean but with important indirect impacts on ocean health, such as agriculture (due to run-off) and waste management, require yet different policies to reduce ocean impacts and damages.

Ocean sustainability extends beyond improving practices in these economic sectors. Direct funding for ocean conservation, such as creation and enforcement of marine protected areas, remains an important component of sustainable ocean finance. Traditionally funded by non-commercial finance, whether public sector or philanthropic, there is a need to create and scale-up financing models that channel revenues from ocean sectors towards conservation activities while also improving practices in those sectors. This would better integrate the goals of conservation of the ocean with those of sustainable use, for example through well-designed taxes and charges, bond proceeds or other means.

While the field of sustainable ocean finance is relatively new, lessons can be drawn from the more established domain of climate finance. First, the ocean and climate change are closely linked, meaning that a subset of sustainable ocean investments are also climate investments, and vice versa, with implications for financing those projects (such as offshore renewable energy; regeneration of coastal carbon sinks). Second, while there are key differences in the incentive and regulatory structures that drive climate and ocean finance more broadly - notably the lack of a single ocean sustainability metric to compare with carbon-dioxide-equivalent for climate - there are also similarities that can provide learning points. One example is the experience gained in the development and refinement of standards for green bonds.

Governments can play multiple roles in driving both scaled up investment opportunities for sustainable activities and redirecting capital away from potentially harmful existing activities. First, by creating the policy frameworks and investment conditions that favour sustainability and act to align incentives and improve enforcement and traceability. Second, by deploying public finance either as direct investment in sustainable activities, in particular those targeting ocean conservation and sustainable use at home and abroad, or by deploying public finance to mobilise private sector capital for investments with a proven sustainability contribution, for example through forms of blended finance and through innovative financial instruments.

The underlying policy and regulatory framework is crucial to promote sustainable investments, including by realigning incentives towards sustainability and improving regulation. Despite the diversity of ocean sectors, there are some common features of this policy framework, such as international agreements and targets, efforts to improve investment conditions domestically (including through better regulation and enforcement), economic instruments that provide public revenue and realign incentives away from harmful practices and setting standards for supply chain transparency (reporting on climate and other nature-related risks). Supporting innovation is also essential both through public funding of research and development and by fostering innovation through the whole chain of innovation and commercialisation.

A number of financial instruments and investment models are emerging that can help to mobilise private capital and better utilise public funding. These include sovereign and corporate "blue bonds", sustainability-linked loans or other debt instruments, and novel insurance mechanisms to capture resilience benefits of natural coast infrastructure. 
Increased use of blended finance in developing countries is also promising, using public funds to mobilise a broader array of funding sources. Blended finance needs to make a clear contribution to sustainability, aiming to change the market and craft new, more environmentally, socially and economically sustainable business models and products in ocean-based sectors, rather than becoming a permanent feature in private investments.

Developing countries often suffer the greatest consequences from global investments in unsustainable ocean economic activities, with impacts spanning fish populations, coasts, tourism, food security, and livelihoods. International development co-operation therefore needs to do more to ensure that sustainability is integrated in traditional financial services and investments, in financial markets (e.g. stocks and bonds), and in credit markets (e.g. loans or bonds). This means ensuring adequate representation of developing countries in key international processes and negotiations linked to ocean use, as well as supporting improved policies, regulations and financial levers for shifting finance from harmful practices towards sustainable activities.

Ultimately, successfully reversing ocean degradation and protecting the essential "ecosystem services" that the ocean provides will require a broader transformational shift across the financial sector. While better ocean regulation, targeted incentives and innovative financial instruments are all important parts of the equation, they need to be accompanied by a wider "resetting" of the financial sector that overcomes short-termism and fully values the material benefits of averting global environmental crises spanning the ocean, terrestrial biodiversity loss and climate change. 


\section{Introduction}

The ocean is integral to our planet's life support system. It is central to human well-being and to all life on earth (Steffen, Rockström and Richar, 2018 $\left.8_{[1]}\right)$. Covering $70 \%$ of the Earth's surface, the ocean is a vast reservoir of biodiversity, containing between $50-80 \%$ of all life on the planet. The ocean and its diverse ecosystems regulate the Earth's climate system, influencing weather patterns and providing protection against storms, The ocean is also a critical social and economic resource with around $40 \%$ of the world's population, or around 3 billion people, living within $100 \mathrm{~km}$ of the coast (CIESIN, 2012 22$]$ ), many of whom depend on the coastal zone and the ocean for their livelihoods. Seafood provides 3.3 billion people with $20 \%$ or more of their protein intake $\left(\mathrm{FAO}, 2020_{[3]}\right)$. Ocean ecosystems are a pillar of tourism in many countries. Beyond food security and tourism, the ocean is profoundly connected with economic performance in many other areas, such as international trade and energy production.

Despite its size, the ocean is vulnerable. The potential for the ocean to continue to underpin livelihoods and economic activity - including through multiple and invaluable ecosystem services ${ }^{1}-$ is threatened by human activities, notably overfishing, the deluge of plastic and other pollution, habitat degradation, invasive species and climate change (IPBES, 2019 $9_{[4]}$ ). These pressures on ocean ecosystems have been intensifying rapidly, as economic activity related to the ocean has grown around the world (OECD, 2016 $\left.6_{[5]}\right)$ (OECD, 2017 $\left.{ }_{[6]}\right)$. Before the COVID-19 pandemic, the global ocean economy - as defined in the next section - was growing fast was projected to continue to grow at twice the rate of the rest of the economy for the coming decade. The crisis resulting from the pandemic has had severe economic and social impacts on several ocean sectors. The speed and nature of the economic recovery will have important implications not only for jobs and livelihoods but also for the sustainability of ocean activities and consequentially on the state of ocean health in the coming years.

The ocean economy is already large, commanding substantial flows of investment and capital from both public and private sources. While data on financial flows to sustainable ocean activities are still patchy, evidence suggests that the scale of these investments is low relative to the overall financial flows to ocean activities, and are funded primarily from philanthropy and official development assistance (ODA) (Friends of Ocean Action, $\left.2020_{[7]}\right)$. This is despite evidence that the benefits of investing in sustainable ocean opportunities are at least five times greater than the costs (Konar and Ding, 2020 ${ }_{[8]}$ ). Currently, only a small proportion of ODA is allocated to ocean activities, and only a small fraction of this is targeted at sustainable activities. In 2013-18 only $0.8 \%$ of ODA targeted sustainable ocean activities relating to the ocean economy, equivalent to USD 1.5 billion on average a year $\left(\mathrm{OECD}, 2020_{[9]}\right)$. Within countries, the revenue collected through environmental ocean taxes is also telling, representing a small proportion of total ocean tax revenue, and a small proportion of total environmentally-related tax revenue across all domains $\left(0.5 \%\right.$, around USD 4 billion in OECD countries in 2018 (OECD, 2020 $\left.0_{[10]}\right)$.

At present, the most financially attractive investments on a conventional business time horizon are likely to increase pressures such as over-exploitation and pollution, rather than mitigating them (WWF, 2019 $9_{[11]}$ ). Public policies and financing have a key role to play to help align private investments to the sustainability imperative of the global ocean economy, creating an enabling environment for sustainable investments as well as policy directions

\footnotetext{
${ }^{1}$ Ecosystem services are the direct and indirect contributions of ecosystems to human well-being
} 
that help shape new, more environmentally and socially sustainable business models and products for ocean-based sectors. However, the diversity of ocean economic sectors - and impacts of those sectors - means that there is no single nor simple solution to ensure that this growth acts to protect ocean health rather than damage it.

The year 2020 was set to be a critical year for international decision-making relating to the ocean, and the closely-linked areas of biodiversity and climate change: the U.N. Ocean Conference in Lisbon, the World Conservation Congress in Marseille, the $15^{\text {th }}$ Conference of the Parties (COP) to the Convention on Biological Diversity in Kunming, and the United Nations Framework Convention on Climate Change COP26 in Glasgow. While the upheaval caused by the COVID-19 pandemic has forced the postponement of those decision points, the COVID-19 crisis has also created an important opportunity for governments to initiate an economic recovery that averts the worst impacts of impending environmental emergencies, including for the ocean. Scientists estimate that the next 10 years are crucial to make the required systemic changes to recover ocean health and safeguard planetary and human well-being.

In that context, this paper sets out a framework for addressing the dual challenge of scaling up sustainable ocean finance and ensuring that financial capital is redirected towards more sustainable activities. It seeks to clarify key concepts around the shift towards a sustainable ocean economy and discusses key challenges and opportunities for scaling up finance across ocean-based sectors. The paper builds on and is complementary to another OECD report on the sustainable ocean economy with a focus on developing countries, launched in September 2020 (OECD, 2020 $\left.{ }_{[9]}\right)$. That report provides fresh evidence on trends in oceanbased industries, policy instruments for improving sustainability, and development finance and development co-operation practices in support of more sustainable ocean economies, notably tracking the volume and scope of official development assistance and private finance mobilised through blended finance arrangements.

\section{Defining and financing a sustainable ocean economy}

\section{What is the ocean economy and what makes it "sustainable"?}

Economic activity related to the ocean, and its impacts on the ocean, is extremely varied. Defining the scope of the ocean economy is therefore challenging, and several different definitions are in common usage. The OECD has previously provided a definition of the ocean economy that comprises not only ocean-based industries but also the marine ecosystems that provide material or service inputs to those industries (OECD, 2016 $\left.6_{[5]}\right)$. This definition is designed to highlight both the crucial role of ecosystems in underpinning ocean-based economic activity, and the important positive and negative impacts that ocean industries can have on ecosystems (Figure 1). The existing practices of ocean industries (and also some land-based industries) have direct or indirect impact on ocean ecosystems, such as overfishing and pollution from aquaculture and fishing equipment, as well as nutrient run-off and plastic pollution from the land.

At the same time, ecosystems provide essential inputs to many ocean industries. The World Wildlife Fund (WWF) conservatively estimates the total "asset" base of the ocean to be at least USD 24 trillion, but cautions that the actual value is likely much higher, in large part due to ecosystem services that are difficult to quantify (Hoegh-Guldberg, 2015 ${ }_{[12]}$ ). Ecosystem services provided by the ocean include provisioning (such as fisheries and aquaculture; fuel from mangroves), regulating (e.g. carbon sequestration and shoreline stabilisation, storm protection, pollution buffering), supporting (e.g. soil formation and 
photosynthesis) and cultural (e.g. tourism, spiritual, aesthetics) services (Millennium Ecosystem Assessment, 2005 $\left.{ }_{[13]}\right)($ OECD, 2017 $[6])$. Some services - such as fisheries and tourism - are more straightforward to quantify economically than others, such as climate regulation.

Figure 1. The OECD concept of the ocean economy

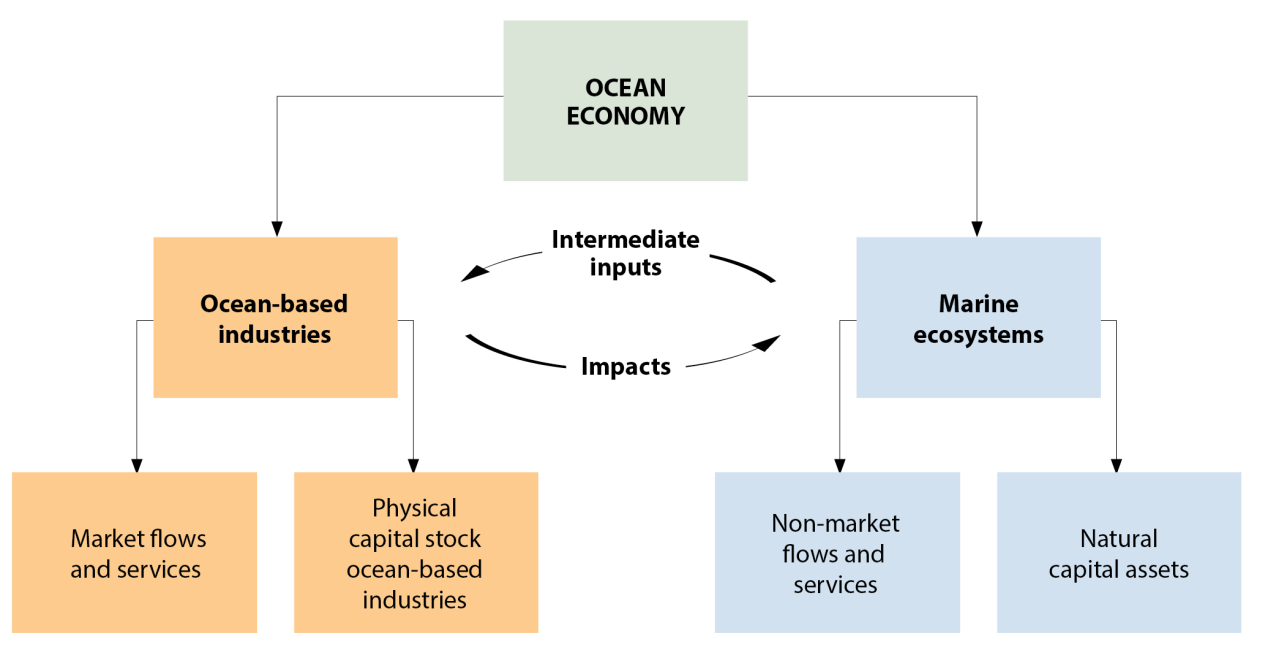

Note: (OECD, 2016[5]) further subdivides ocean economies into "established" industries, such as capture fisheries, shipping, ports and oil and gas and "emerging" industries, such as aquaculture, off-shore renewables, seabed mining and surveillance

Source: (OECD, 2016[5]).

While defining the scope of the ocean economy is not straightforward, defining the perimeter of the "sustainable" ocean economy is even more challenging. Threats to the "health" of the ocean are multiple and wide-ranging, and the implications of those threats for the future of the ocean and the world are complex (Box 1). Furthermore, sustainability also has a social component, and it is important that decreased environmental impacts are closely aligned with social considerations, including improving livelihoods for the hundreds of millions of people directly dependent on the ocean.

Current practices of ocean industries impact the ocean in many different ways, meaning that there are several dimensions to how sustainability can be considered across those sectors. For example, reducing the ocean economy's contribution to climate change - such as through reducing emissions from ocean operations (e.g. shipping) and by displacing emissions from the wider economy (e.g. offshore renewables) - is one dimension. Another key dimension is preventing damage to marine ecosystems from ocean and land-based activities (such as via overfishing and pollution) and enhancing the natural assets and capital that support a large part of the ocean economy and livelihoods. Valuing investments that build resilience, including those that protect natural assets from physical damage, is also an important pillar of ocean sustainability.

It is therefore important to take a sector-by-sector approach to defining and measuring ocean sustainability, with implications for categorising and financing ocean investments. Investments and operational changes that improve each of these and other dimensions of 
ocean sustainability represent important steps towards reducing the broader environmental impact of the ocean economy. However, examining each element in isolation is not sufficient. In particular, there are often synergies and trade-offs between the different dimensions of sustainability. Even if an action leads to a clear improvement for one environmental objective, it is important that the action does not have detrimental effects on other dimensions; this is similar to the concept of "do not significant harm" embodied in the EU taxonomy for sustainable finance (discussed further below).

Sometimes synergies are clear, such as actions that improve the resilience of coastal communities while also supporting regeneration of ocean ecosystems and reducing net greenhouse gas (GHG) emissions - for example the regeneration of mangrove forests. Other actions present trade-offs. For example, off-shore wind turbines can make a substantial contribution to reducing GHG emissions from land-based electricity generation, but depending on their siting may threaten biodiversity both below and above water. Another example is deep seabed mining for critical minerals (e.g. for new energy and digital technologies) that could reduce land-based impacts but have serious impacts on ocean ecosystems.

Several attempts are emerging to unpack the various dimensions of sustainability across ocean-based sectors and define criteria for sustainable ocean finance. For instance, OECD (OECD, 2020[9]) examines development finance to six ocean-relevant sectors to identify the scope and nature of sustainable activities within each sector (i.e. sustainable fisheries; sustainable tourism; renewable ocean energy; greening ports and shipping; ocean conservation; the reduction of ocean pollution from land activities). Both the United Nations (UN) Global Compact and the Initiative for the Sustainable Blue Economy Finance Principles are working to develop taxonomies for sustainable ocean finance.

\section{Box 1. Threats to a healthy ocean}

Marine ecosystems provide essential services by way of food, medicine and water provisioning, climate regulation, through processes such as the uptake and redistribution of carbon dioxide and heat, as well as storm protection, shoreline stabilisation, and many more. The ocean also directly supports economic activities, including renewable energy generation, maritime transport, trade and tourism. However, pressures on the ocean - in particular from climate change, pollution, over-exploitation, marine habitat degradation and invasive alien species - are threatening the stability of ocean ecosystems and the lifesupport functions they provide (IPBES, 2019 $\left.9_{[4]}\right)$.

- Climate change. The Intergovernmental Panel on Climate Change (IPCC) estimates that the global ocean has warmed unabated since 1970 and has absorbed more than $90 \%$ of excess atmospheric heat (IPCC, 2019 $9_{[14]}$ ). The incidence of marine heatwaves has doubled and are increasing in intensity. This process of heat absorption is changing the ocean's chemistry, resulting in ocean acidification and a loss of oxygen. Increasing acidity reduces some species' ability to form shells and skeletons. Coral reefs have nearly halved in the last 150 years (IPBES, 2019 ${ }_{[4]}$ ), with warm water corals projected to suffer significant losses of area and local extinctions even if global warming is constrained to 1.5 degrees Celsius (IPCC, 2019 [14]]). Ocean industries contribute to GHG emissions that drive climate change. For example, international shipping 
accounts for around $2 \%$ of total energy-related carbon dioxide $\left(\mathrm{CO}_{2}\right)$ emissions, a proportion that was growing fast before COVID-19 (IEA, 2020 $0_{[15]}$ ).

- Pollution. The ocean is under increasing stress due to pollution from multiple urban and rural sources, notably solid and liquid wastes from cities, pharmaceutical residues, fertiliser and manure run-off from farming, air emissions from shipping, and plastic from land-based and sea-based sources. Eutrophication - caused by excessive nutrient pollution (typically nitrogen and phosphorus from agricultural and industrial run-off) - can trigger toxic algal blooms and cause "dead zones" (oxygen depletion) in the ocean and coastal waters leading to significant loss of marine biodiversity. The number and size of ocean dead zones has doubled each decade since the 1960s, mostly due to nutrient pollution from agriculture $\left(\mathrm{OECD}, 2018_{[16]}\right)$. Marine plastic and microplastic pollution affects the environment and marine ecosystems through, for example, ingestion or entanglement by species who live in them, thereby both affecting those species and entering the food chain. Marine plastic pollution in particular has increased tenfold since 1980, with up to 13 million tonnes estimated to be introduced to the ocean each year (Jambeck et al., $2015_{[17]}$ ). Approximately $80 \%$ of marine plastic debris originates from land-based sources and is transported to the ocean through rivers, with the remaining share of debris coming from fishing activities, natural disasters and other sources. Air pollution from ships, including particulate matter and oxides of sulphur and nitrogen, is a major issue for coastal zones. Premature deaths attributable to air pollution shipping have been conservatively estimated at around 60000 per year, around $15 \%$ of the total deaths attributed to pollution from transport (ICCT, 2019 $9_{[18]}$ ).

- Unsustainable fishing. The Food and Agriculture Organization estimates that a third of global fish stocks are fished at biologically unsustainable levels, up from $10 \%$ in $1974\left(\mathrm{FAO}, 2020_{[3]}\right)$. Illegal, unreported and unregulated (IUU) fishing is a threat to fisheries and the communities that depend on them. Government support to fisheries can sometimes be harmful to the long-term health of the sector by encouraging overfishing and over-exploitation, as well as being inefficient at supporting fishers (in particular through fuel support) (Martini and Innes, 2018 [19] ). Climate change further threatens fisheries and the livelihoods that depend on them, with the IPCC warning that changes in the spatial distribution and abundance of some fish stocks are expected to have negative impacts particularly for Indigenous and local communities dependent on fisheries (IPCC, 2019 ${ }_{[14]}$ ).

- Habitat destruction. A variety of human activities can have adverse impacts on biodiversity habitats and the ecosystem services they provide. Seabed habitats, for example, can be adversely impacted by bottom trawling, deep-sea mining and marine litter. Certain marine ecosystems, particularly in the deep sea, are not well understood, meaning that mitigation measures needed to protect these ecosystems from potential threats, as well as their potential value (e.g. for medical treatments and other innovations) may also not be understood or tested. As well as providing food and other resources, coastal ecosystems play a vital role in protecting the shoreline from extreme weather, which is set to increase due to the effects of climate change. Coastal ecosystems such as mangroves, seagrass meadows and tidal marshes are themselves important stores of "blue carbon", and their restoration could result in increased carbon uptake and storage of around $0.5 \%$ of current global emissions annually (IPCC, $\left.2019_{[14]}\right)$. However, these ecosystems are increasingly threatened. Seagrass meadows 
decreased by over $10 \%$ per decade from 1970 to 2000 (IPCC, $2019_{[14]}$ ) and $20 \%$ of the total area of mangroves was lost between 1980 and 2005 (FAO, 2007 $[20]$ ).

- Invasive alien species. Non-native species introduced to marine ecosystems is classed as a key driver of species decline, accounting for around $10 \%$ of the global decline in marine biodiversity (IPBES, 2019[4] $)$. Invasive alien species in the marine context can be introduced through ship ballast and ship hulls, and can have adverse impacts including altered native ecosystems, decreased water quality, displaced native organisms and disease spread. This can also have negative economic impacts through fish stock collapse, damage to coastal areas and control costs (OECD, 2017[6]).

\section{What are the key challenges in scaling up sustainable ocean finance and investment?}

The diversity of ocean economy activities - and the many dimensions of what it means for those activities to be "sustainable" - means that the challenges and opportunities for sustainable financing and investment vary greatly. Nevertheless, there are some commonalities across ocean sectors in terms of the key reasons that many economic activities and investments in the ocean are currently harmful to the long-term health of the ocean, and why sustainable activities are often less economically attractive than unsustainable or harmful activities

One of these commonalities is that economic returns do not sufficiently account for the negative environmental impacts of activities. Environmental impacts vary in type and magnitude across ocean sectors, represented in economic terms as a range of different externalities that are not priced into either economic returns or financing costs. As a result, these environmental impacts have insufficient bearing on the financial materiality of firms. For some environmental dimensions, the metric for integrating impacts is clear, such as a price on measurable GHG emissions (or avoided emissions). For other, more complex environmental impacts, the metric to integrate them to financial concerns is less clear, making it hard to create revenue streams from sustainable activities. ${ }^{2}$

Another related commonality is that the benefits provided by the ocean's natural environment both now and in the future - including ecosystem services - are not sufficiently valued. Capturing (or at least recognising) this value of these positive externalities is a challenge for many reasons, partly because the mechanisms for how the systems function are not well understood in specific contexts (e.g. how changes in composition and structure of ecosystems leads to changes in ecosystem services) and because the flows of these services are difficult to quantify given the inherently fluid nature of ocean resources.

The characteristics of the ocean environment itself have an important bearing on financing ocean activities in general, as well as for sustainable activities. Even before considering sustainability, ocean sectors present particular circumstances and risks that have a strong bearing on financing. The physical characteristics of the ocean can lead to greater financial risk for ocean-related activities $\left(\mathrm{OECD}, 2016_{[5]}\right)$. As a result, ocean firms and entrepreneurs often face higher financing costs or more challenging conditions to attract finance. The

\footnotetext{
2 The notion of double materiality, separating financial materiality from social and environmental materiality, has been proposed in the EU guidelines on non-financial reporting https://eurlex.europa.eu/legal-content/EN/TXT/PDF/?uri=CELEX:52019XC0620(01)\&from=EN
} 
ocean is an extreme environment where infrastructure and equipment tends to suffer and can be expensive to repair (such as off-shore wind turbines, oil and gas platforms). Ocean activities can be subject to severe weather risks (e.g. artisanal fisheries with days at sea lost because of storms; delays and accidents in shipping). Increasingly, ocean-based activities are also exposed to pollution that can have economic impacts on their business (aquaculture yields dropping; tourism impacted by beaches closed because of plastic pollution and landbased runoffs, etc.). For example, financial losses to fisheries and tourism from plastic pollution, including time for beach clean-up, is estimated at around USD 13 billion annually (UNEP, 2014[21]).

The physical nature of the ocean also has implications for financing sustainable ocean activities. It can be difficult to define and enforce access and property rights in the ocean because of remoteness (including areas beyond national jurisdictions) and because many economic assets are hard to observe, such as fish populations. Additionally, the remote nature of some activities can make enforcement challenging and expensive. This makes it difficult for regulators to systematically penalise damaging activities, meaning that competing sustainable activities may find it harder to attract financing (for example, competing against IUU fishing or illegal ballast water discharges from shipping). Further, the services provided by the ocean have characteristics of "public goods", for example the conservation and health of the vast ocean resources of some of the smallest and most remote island states in the world (small island developing states) effectively helps to preserve critical ocean functions to the benefit of the entire planet.

Given that these various environmental impacts vary both in the nature of the externality they represent and in their relevance to different economic sectors, it is helpful to reframe the ocean economy in a way that first considers which sectors can negatively impact the ocean, and then distinguishes those sectors according to their relative dependence on the ocean and ocean ecosystems (Figure 2). The reason for classifying sectors in this way is that the underlying policies and incentives needed to finance sustainability are likely to differ across these domains:

- Sectors dependent on ocean natural capital and ecosystems: some key ocean activities directly rely on living ocean resources to support their economic activity, including wild-capture fisheries, tourism and bio-prospecting. Aquaculture can also be considered in this category due to its reliance on clean water, wild fish for stocking and in some cases feed. In many cases, these sectors already successfully monetise ecosystem services to generate near-term returns and to attract financing. A key requirement for shifting investment to sustainably managed activities is to successfully capture the future value of the natural assets, in addition to the immediate returns from near-term exploitation. This means finding ways to value tomorrow's revenue as well as today's, going beyond the principle of "do no harm" to actively support the conservation and restoration of marine ecosystems.

- Sectors not dependent on ocean natural capital but physically present in the ocean and with potentially severe impacts: several economic sectors are physically present in the ocean and can therefore still have critical impacts on ocean ecosystems, even though they do not depend on natural assets as economic inputs. These sectors include shipping (and ports), energy production and generation

\footnotetext{
${ }^{3}$ A public good is a good that is both non-excludable and non-rivalrous, in that individuals cannot be excluded from use or could benefit from the good without paying for it, and where use by one individual does not reduce availability to others
} 
(whether renewable or fossil-fuel based). For these sectors, reducing impacts on ocean health mostly involves improved regulation, incentives and awareness. There may be trade-offs between sustainability objectives, for example offshore renewable energy may be financed through climate change policy incentives, but potential impacts on ocean ecosystems need to be considered through separate policy mechanisms.

- Sectors with no direct connection to the ocean but with significant potential impacts on it: key land-based sectors are critical to reduce impacts on ocean ecosystems, even though they may be physically far from the ocean and their activities seemingly unconnected from it. Key examples are waste management (both solid waste and water treatment) and agriculture, because of nutrient run-off from heavy fertiliser use. From an ocean sustainability perspective, policy challenges include building awareness of the sometimes distant effects on ocean health in order to foster a more integrated policy framework, and the development and implementation of adequate regulations and incentives to encourage practices with lesser effects on the ocean.

Figure 2. Reframing ocean-relevant sectors

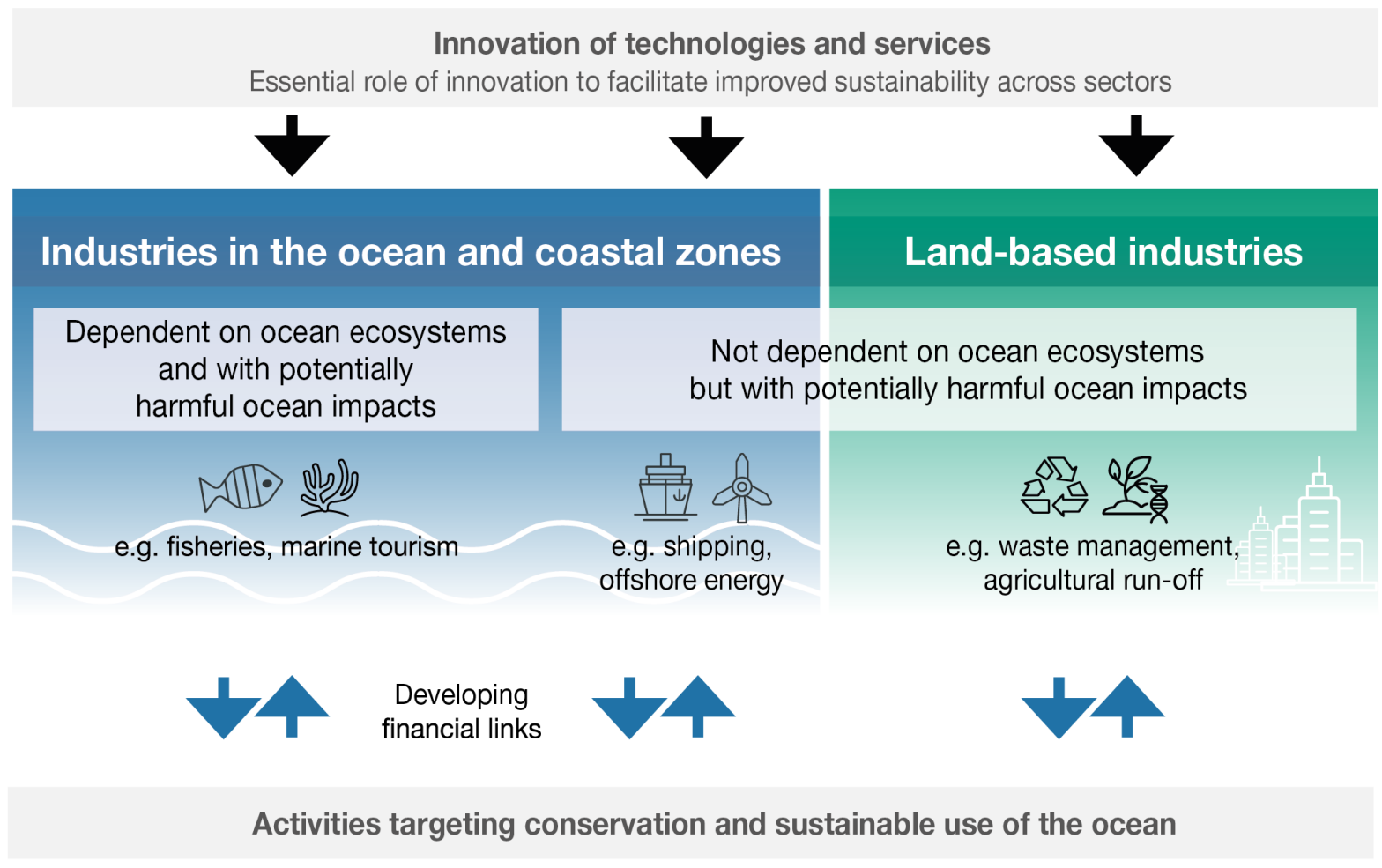

Source: Authors

The economically productive sectors covered by this framework are those that have the greatest impact on the ocean and where key opportunities lie to lessen and reverse those impacts, by reorienting capital away from harmful activities. This requires integrating ocean risk in all ocean-related investments via adequate regulations and policy levers, 
including economic instruments, as well as introducing new financing instruments and policies that tie access to capital to sustainability improvements, as discussed below.

In addition to improving sustainability across these economic sectors, direct funding for ocean conservation, such as creation and enforcement of marine protected areas, remains an important component of sustainable ocean finance. Public funding is currently limited, and most estimates show that the full cost of establishing and operating marine protected areas in line with global goals would far outstrip available conservation funding, even though the net benefits of ambitious marine protection goals (such as $30 \%$ of countries' EEZs) would significantly outweigh the costs (Brander et al, 2015). Another piece of the ocean finance picture is therefore the need to create and scale-up financing models that link ocean sectors with funding for conservation and sustainable use, for example through well-designed taxes and charges or other revenue raising instruments, as discussed below.

Finally, an important lever for improving ocean health and improving the business case for sustainability is supporting and funding innovation. Solving the ocean health challenge will require substantial innovation across ocean sectors, at many different points of the value chains that make up those sectors (OECD, 2019[29]). Examples range from innovative hardware for sectors dependent on ocean ecosystems (such as advanced fishing tackle to reduce by-catch); to systems that facilitate transparency and enforcement of regulations (such as real-time satellite imagery and block-chain supply chain traceability). Other important innovations may come from outside the ocean sphere, such as development of insect protein to reduce the impacts of aquaculture, improvement of filtering for microplastics in the wastewater management chain and improvements in design of plastics to increase recycling rates. Creating the conditions to accelerate the innovation process - including through public research and development (R\&D) funding and encouraging private investment in innovation - is an important additional policy dimension important challenge that is important to the overall ocean sustainability picture.

\section{What can sustainable ocean finance learn from climate finance and investment?}

While the need for financing the sustainable ocean economy has increased rapidly in profile in recent years, the broader field of "green" financing has witnessed a much longer period of focus and development. In particular, there is now a rich body of research on designing incentives and financing instruments for activities related to climate change, as well as defining and measuring financial flows. There is also now extensive practical experience ranging from private sector to public financial institutions such as multilateral and national development banks. This experience can provide valuable lessons for sustainable ocean finance. Additionally, lessons can be drawn from experience in financing for biodiversity which naturally includes marine ecosystems.

Action on climate change is usually categorised into mitigation (reducing GHG emissions in order to prevent build-up of greenhouse gases in the atmosphere) and adaptation (often defined as adjustment in natural or human systems in response to expected effects of climate change). While more attention has traditionally been focused on climate change mitigation, in recent years there has been an increasing recognition of the importance of adaptation. Climate finance also has important international dimensions, including relating to the commitments of developed countries to mobilise climate finance to support the needs of developing countries.

There are at least two main ways that the experience built up with climate finance can provide useful lessons for financing sustainable ocean activities. Firstly, the ocean and climate change are very closely linked, meaning that a subset of sustainable ocean 
investments are also climate investments, and vice versa, with implications for financing. Secondly, while there are key differences in the incentive and regulatory structures that drive climate and ocean finance more generally, there are also similarities that can provide learning points.

Ocean and climate are inexorably linked. The ocean regulates the climate at a global scale, both in terms of $\mathrm{CO}_{2}$ absorption and temperature buffering. With rising $\mathrm{CO}_{2}$ levels and accelerating climate change, both these properties are having an increasing effect on the ocean itself, with both acidification and warming water severely impacting ocean ecosystems and the capacity of the ocean to absorb $\mathrm{CO}_{2}$. On the other hand, ocean economy sectors and economic activities can influence global climate change through their potential to increase, decrease or displace GHG emissions. Two examples are ocean energy resources - whether fossil or renewable - and managing the carbon balance stored and emitted by coastal ecosystems, or even by ocean fauna such as whales (Chami et al., $2019_{[22]}$ ). Coastal ecosystems are also important elements for climate change adaptation of coastal communities, protecting against increasingly severe storms. The ocean also therefore plays an important role in adaptation and for 'nature-based solutions' both for mitigation and adaptation.

From a financing perspective, there are a number of similarities and differences between climate finance and sustainable ocean finance that stand out. Climate finance and ocean finance share the double challenge of needing to not only scale-up finance for new sustainable activities, but also to reallocate capital away from established, potentially harmful activities and industries, which are powerful and important for the economy and jobs.

As well as being more widely studied and practised to date, climate finance has some characteristics that make it simpler and easier to define than ocean finance. One key element of this is the single underlying metric that exists for measuring impacts on climate change mitigation (tonnes of $\mathrm{CO}_{2}$-equivalent). This allows policies and financial instruments to be designed around valuing and measuring impact on this particular metric (although this applies only to mitigation, not adaptation).

Ocean sustainability is much broader, and has no such single metric. However, where ocean activities also deliver climate mitigation benefits, the measurement and valuing of reduced or avoided GHG emissions can be an important driver of ocean finance. For off-shore renewables, the incentive structure is similar for other (land-based) low-carbon energy, albeit with some differences: the physical harshness of the ocean environment pushes up technology and financing costs (including transmission costs) meaning that a carbon price alone may not support the business case. Additionally, there is the need for careful permitting and siting to prevent damage to sensitive marine environments, which may be more complex than land-based equivalents. Additionally, pricing avoided GHG emissions can also help to finance the protection and regeneration of coastal ecosystems such as mangroves, by valuing their role as carbon sinks. In this way the mitigation potential of these ecosystems acts to protect their other benefits and ecosystem services, such as protecting coastal communities from storms and providing a nursery ground for commercially important fish species. This "blue carbon" model depends on a robust carbon market that creates demand for this particular ecosystem service (discussed below).

More generally, there are common challenges across the wider "sustainable finance" sphere. In the EU, a sustainable finance taxonomy has been developed to guide investors, companies, bond issuers and governments in understanding what can be considered "sustainable". The taxonomy identifies six environmental objectives; ocean-related 
investments are grouped together with freshwater resources under a single item. While most of the effort to date has focused on climate-related activities, the taxonomy clearly underlines the interconnected nature of the environment by stipulating that even an activity focused on only one of the objectives must "do no significant harm" to all of the other five. This helps to ensure that different environmental actions are at least aligned - for example that projects aimed at reducing GHG emissions in the ocean cannot be considered sustainable if they are doing significant harm to ocean ecosystems.

The taxonomy approach can help overcome an issue often raised by financiers and policymakers seeking to finance sustainable investments, whether with a climate, ocean or other focus: that it is a lack of "bankable" projects that holds back progress, rather than a lack of available capital (though due to the COVID-19 crisis, capital is more constrained than it was previously). In other words, available projects are perceived to not meet investors' needs, whether in terms of risk, return or other factors. While the definitional clarity provided by a taxonomy can help to increase confidence and reduce perceived risk, a wellaligned and long-term policy environment is essential to further build the sustainability investment case whether in climate, ocean or other objectives (OECD, 2020[23]).

Another key area where experience from climate finance can be useful for the ocean sphere is transparency and in particular the reporting of climate-related risks facing firms or investors. The guidelines of the Taskforce on Climate-related Financial Disclosure (TCFD) are currently voluntary but encourage firms to transparently report on their exposure to climate risks, both in terms of physical risks (how a changing climate might affect the value of their operations over time) and transition risks (how much companies are exposed to decarbonisation policies aiming to mitigate climate change). The complexity and diversity of the ocean sphere means that many investors are unaware of the risks and opportunities surrounding sustainable ocean investments, as shown by a recent survey (Fritsch, 2020 [24]); a concerted international effort to improve transparency and reporting could help in this regard. Work is underway to develop a Taskforce on Nature-related Financial Disclosure, in the mould of TCFD. Additionally, several initiatives to promote principles for sustainable ocean investment are a helpful development in this regard (see Box 2).

Finally, recent years have seen an increase in experience with a number of financial instruments aiming to raise finance for climate-focused projects. These can also provide lessons for sustainable ocean finance, despite the many differences related to valuing and monetising environmental benefits related to the ocean. One key area relates to how to mobilise debt capital markets through targeted bond instruments. Issuance of green bonds related to climate action has grown rapidly recently with particularly strong growth in 2019 (reaching USD 257bn annual issuance). While issuance rates have fallen off sharply in 2020 due to COVID-19, the accumulated experience is nevertheless substantial.

Over time, methodological aspects of green bonds have improved through development of standards and ratings to identify and verify the "greenness" of the bonds' use-of-proceeds. These standards could also inform development of bonds specific to oceans - "blue bonds" - as well as green bonds that are used to finance activities with positive impacts for oceans, even directly. As the green bond market developed, it diversified from public sector issuers (sovereign and development banks) towards a greater share of corporate issuances from financial and non-financial firms. While the focus on "blue bonds" for sustainable oceans has so far focused on public sector issuances, there is nevertheless scope for capitalising on growing corporate interest in sustainable ocean finance. However, development of a robust market will require development of methods and standards to ensure the sustainability of how the funds are used (discussed further below). 
Table 1. Comparing and contrasting sustainable ocean finance and climate finance

\begin{tabular}{|c|c|c|}
\hline & SIMILARITIES & DIFFERENCES \\
\hline Overall challenge & $\begin{array}{l}\text { - Both climate change and ocean health require both a scaling } \\
\text { up of financing for sustainable activities and redirection of } \\
\text { investment away from unsustainable practices } \\
\text { - Both ocean and climate change face path dependencies (e.g. } \\
\text { lock-in of infrastructure and harmful practices, inertia of status } \\
\text { quo, and multiple policy misalignments that mask price signals } \\
\text { and make sustainable investments riskier) }\end{array}$ & $\begin{array}{r}\text { - The breadth of ocean sustainability dimensions makes it } \\
\text { harder to identify clear and stable revenues for some } \\
\text { sustainable ocean investments (such as sustainable } \\
\text { fisheries and coastal resilience) than it is for climate } \\
\text { mitigation } \\
\text { Shifting investment time-frame: for some ocean } \\
\text { investments, payback from sustainability is longer-term } \\
\text { than land-based climate mitigation }\end{array}$ \\
\hline Definitions & $\begin{array}{l}\text { - Conclusive definitions on what is "sustainable" or "green" are } \\
\text { hard to achieve due to wide array of possible environmental } \\
\text { and social impacts (e.g. nuclear; off-shore wind; aquaculture) }\end{array}$ & $\begin{array}{l}\text { - GHG mitigation objective is clear and measurable, even } \\
\text { if measurement differs across sectors and gases } \\
\text { - Identifying, defining what is sustainable for oceans is } \\
\text { harder (climate is only one part of it); }\end{array}$ \\
\hline Target Sectors & $\begin{array}{l}\text { - Many economic sectors relevant both for climate change and } \\
\text { ocean sustainability }\end{array}$ & $\begin{array}{l}\text { - Climate change is relevant for almost all sectors across } \\
\text { the economy (though a few are critically important) } \\
\text { - While only a subset of the economy is relevant for } \\
\text { oceans, some sectors with key ocean impacts are far } \\
\text { removed from the ocean itself (plastics; agriculture run- } \\
\text { off) }\end{array}$ \\
\hline $\begin{array}{l}\text { Understanding } \\
\text { investment } \\
\text { needs, current } \\
\text { flows and gaps }\end{array}$ & $\begin{array}{l}\text { - Defining, measuring and tracking "sustainable" financial flows } \\
\text { are challenging in both domains }\end{array}$ & $\begin{array}{l}\text { - Investment needs and current investment flows for low- } \\
\text { carbon are generally quite well understood } \\
\text { - Ocean investment, and sustainable ocean investment is } \\
\text { harder to characterise } \\
\text { - Activities with key impacts on oceans are far removed } \\
\text { from ocean }\end{array}$ \\
\hline $\begin{array}{l}\text { International and } \\
\text { national target } \\
\text { setting and goal } \\
\text { framework }\end{array}$ & $\begin{array}{l}\text { - SDGs exist for both climate and ocean (SDG13 and 14) with } \\
\text { other SDGs relevant }\end{array}$ & $\begin{array}{l}\text { - National low-carbon policy frameworks (NDCs) and } \\
\text { international climate frameworks (including the Paris } \\
\text { Agreement) are generally more developed than those } \\
\text { focused on oceans }\end{array}$ \\
\hline Investment risk & $\begin{array}{l}\text { - Risks from new technologies and business models } \\
\text { compounded in some cases by policy risk (e.g. loss of } \\
\text { incentives due to policy U-turn) }\end{array}$ & $\begin{array}{l}\text { - Double challenge for risk perception: ocean } \\
\text { environment is inherently risky; sustainability can present } \\
\text { additional policy and technology risks }\end{array}$ \\
\hline $\begin{array}{l}\text { Enabling } \\
\text { environment }\end{array}$ & $\begin{array}{l}\text { - Improving overall investment conditions is essential (rule of } \\
\text { law, regulatory risk, currency risk) }\end{array}$ & $\begin{array}{l}\text { - Enforcement of regulation and ownership rights } \\
\text { particularly important - and challenging - for remote } \\
\text { ocean environments }\end{array}$ \\
\hline $\begin{array}{l}\text { Resetting } \\
\text { incentives for } \\
\text { sustainability }\end{array}$ & $\begin{array}{l}\text { - Entrenched subsidies for fossil fuels prevalent, including } \\
\text { poorly targeted support for fisheries (e.g. for fuels) } \\
\text { - Market creation instruments (standards, labelling, } \\
\text { certification) exists for energy efficiency and carbon } \\
\text { footprinting, as well as for seafood products }\end{array}$ & $\begin{array}{l}\text { - The key economic incentive mechanism for climate - } \\
\text { carbon pricing - is economically easier to design and } \\
\text { implement than capturing future value of preserved } \\
\text { natural ocean capital }\end{array}$ \\
\hline $\begin{array}{l}\text { Awareness of } \\
\text { investors and } \\
\text { financial } \\
\text { community }\end{array}$ & $\begin{array}{l}\text { - Investment opportunities and risks relating to both climate } \\
\text { and ocean are relatively poorly understood across the financial } \\
\text { sector, though this is changing fast on the climate side }\end{array}$ & $\begin{array}{l}\text { - Sustainable ocean finance is behind climate finance in } \\
\text { terms of awareness of opportunities and risks (climate } \\
\text { issues now well-known, TCFD etc.) } \\
\text { - EU Taxonomy of Sustainable Finance highlights the } \\
\text { prominence of climate change in the green finance } \\
\text { sphere } \\
\text { - In seafood, shareholder pressure harder to exert than } \\
\text { for (e.g. fossil-fuel firms) because each major firm has a } \\
\text { unique cohort of shareholders, there are few common } \\
\text { institutional shareholders across firms }\end{array}$ \\
\hline $\begin{array}{l}\text { Financial } \\
\text { instruments }\end{array}$ & $\begin{array}{l}\text { - Potential for a taxonomy approach to identify sustainable } \\
\text { activities can be appropriate } \\
\text { - Good scope for corporate bonds as well as sovereign bonds } \\
\text { targeted to ocean as well as climate- } \\
\text { - Scope for well-designed Public-Private-Partnerships }\end{array}$ & $\begin{array}{l}\text { - Definitional issues mean identifying use-of-proceeds for } \\
\text { bonds more challenging for some ocean activities } \\
\text { - Some activities with key impacts on oceans are far } \\
\text { removed from ocean }\end{array}$ \\
\hline
\end{tabular}

Source: Authors 


\section{Mobilising ocean finance: capital, policies and investment models}

The previous sections identified the key challenges associated with defining and mobilising finance for sustainable ocean activities. To scale-up financial flows - and reallocate existing flows to more sustainable activities - a strong policy framework is required, targeted towards aligning private finance to sustainability and co-creating and co-shaping new sustainable products and business models. This section begins by assessing the different types and sources of capital relevant to ocean finance, and discusses the underlying policy and regulatory conditions that influence allocation of capital. It concludes with an overview of financial instruments that could be effective in helping to mobilise finance for sustainable ocean-based activities and ocean conservation.

\section{Types and sources of capital relevant to ocean finance}

Strategies to align more public and private investment to sustainable ocean activities need to be targeted towards the different pools of capital that exist in different countries, and the characteristics and expectations of that capital in terms of risk appetite and returns.

Most conventional ocean industries are financed commercially, for example through private equity, stock-market offerings and debt through bank loans. This commercial capital is usually seeking maximum market returns, with little or no sustainability constraints. At the other end of the spectrum, public grants, international overseas development assistance and most philanthropic donors provide capital aiming at maximum social and environmental impact, without expecting financial returns at all (or, in some cases, providing public loan guarantees or "first-loss" loans that act to reduce risk for other investors). In between, a number of actors provide both debt and equity financing with below-market return expectations but with varying degrees of requirements on environmental and social sustainability improvements. Examples include concessional loans and equity from development banks (national and multilateral), impact investors seeking social and environmental impact and, increasingly, sustainability-oriented investment funds seeking to match adequate current returns with long-term value through sustainability (notably “environmental, social and governance” ESG funds).

Currently, because ocean conservation and sustainable economic activities usually have low (or no) financial returns, they are often funded by (national or international) public finance or private philanthropy. With the right policy frameworks, for-profit investments can help fill the funding gap in some sectors and public finance, including ODA, can be used to attract the private sector by tilting the playing field towards sustainability and cofinancing demonstration projects with low profit but strong positive impacts on sustainability (see section on blended finance arrangements below). However, for ocean conservation projects, for instance, generating profitable returns for investors is challenging, and private investments in conservation remain small, marginal and geographically constrained (Dempsey and Suarez, 2016 $[25])$. The reallocation of a portion of tax revenues from ocean sectors towards ocean conservation is therefore also an important component. For instance, several countries are experimenting new schemes and approaches to channel revenues from the fisheries and tourism sector towards conservation activities or insurance schemes that would help restore ocean assets in case of natural hazards (see also section above). 


\section{Policy and regulatory frameworks for scaling-up sustainable ocean finance}

Delivering the investment needed for a sustainable ocean economy requires underlying policy and regulatory conditions that lead capital to shift from unsustainable, even if very profitable, economic activities to ocean activities that create environmental, social and economic value. Although many ocean industries are funded through private investment, financed commercially, such financing is nonetheless guided by regulations, taxes, subsidies and other policy tools. Policy conditions can act to improve the investment case for sustainable ocean projects by improving the risk-return balance, which is an important factor even for non-return-seeking capital.

Despite the diversity of ocean sectors and the specificity of different country conditions, there are some common features of policy that apply across sectors and countries. These features include international agreements and targets, efforts to improve investment conditions domestically (including through better regulation and enforcement), as well as policy instruments to realign incentives away from harmful practices and to promote and mandate sustainable practices. Reorienting public financial support is also important, in particular for sectors where such support plays an important role in guiding investment and operational decisions, such as wild-capture fishing.

\section{International targets, frameworks and governance.}

The ocean investment climate is impacted by international governance in several ways. One way is through binding and non-binding international targets and commitments on governments' own policies within their areas of jurisdiction, both on land and in their ocean exclusive economic zone (EEZ) ${ }^{4}$. These can be reinforced through bilateral or regional agreements to clarify jurisdictional issues. More widely, international law has direct implications for areas beyond national jurisdiction, such as the high seas.

International targets include high-level global goals, such as the SDGs (notably SDG 14 "Life Under Water" but also others with relevance for oceans) and the Aichi biodiversity targets set under the Convention on Biological Diversity (CBD) (such as target 11 to protect $10 \%$ of coastal and marine areas, target 6 on sustainable fisheries and aquaculture, and many more). These do not have direct binding implications for individual countries, but are important for setting the global context, guiding national commitments, raising awareness and increasing peer pressure. Other international targets have a legal framework with a more direct impact on national regulations: for example, targets applied under the Ramsar Convention on Wetlands of International Importance especially as Waterfowl Habitat and the Convention on the Conservation of Migratory Species of Wild Animals (CMS), and the MARPOL convention for pollution from shipping.

From an investment perspective, bilateral or regional agreements can also be important to clarify jurisdictional responsibilities where they concern shared common ocean economy resources, such as fisheries, oil and gas, and mining, or when the activities of one jurisdiction may impact on the ocean resources of another jurisdiction (for example, in the case of migratory fish). The complexity of maritime regions that are shared between countries can dilute ownership, or create competition for shared resources.

Outside EEZs lie Areas Beyond National Jurisdiction (ABNJ), which make up nearly twothirds of the surface of the ocean and nearly $95 \%$ of the ocean's volume (FAO, 2017 $7_{[26]}$ ).

\footnotetext{
${ }^{4}$ The United Nations Convention on the Law of the Sea (UNCLOS) defines the EEZ of a country as extending out to 200 nautical miles from its coast
} 
Because no single state governs the $\mathrm{ABNJ}$, conserving and sustainably managing its resources can be extremely complex. A new international treaty for the conservation and sustainable use of biodiversity beyond national jurisdiction (BBNJ) is currently under negotiation at the UN. The new treaty could provide an opportunity to curb and address the impacts of overfishing on the high seas and enable a more inclusive and sustainable use of high seas resources to the benefit of all countries (OECD, 2020 ${ }_{[9]}$ ).

Some cross-boundary examples of regional agreements to govern the use of shared resources exist. For example, Regional Fisheries Management Organisations (RFMOs) are intergovernmental fisheries management bodies with country parties whose objective is to ensure the long-term conservation and sustainable use of the fishery resources, and whose mandate sometimes extend to the protection of marine ecosystems within RFMO agreement areas.

In the case of shipping, the MARPOL convention to regulate pollution from ships has been in place since the 1970s. Originally conceived in response to oil tanker accidents, the convention has been regularly updated and expanded over the years. Through its Annex VI, it now covers pollution from sewage and garbage from ships, and most recently air pollution and GHG emissions. The latest revision of Annex VI brought new strict standards on sulphur emissions from ships, effective from 2020, as well as progressive reductions in nitric oxides. The Annex also includes requirements for energy efficiency and $\mathrm{CO}_{2}$ reductions. In addition, in 2018 the International Maritime Organization adopted an initial GHG strategy with far reaching implications, calling for a peak in total shipping emissions and a decline by at least $50 \%$ by 2050 (IMO, n.d.[27]).

Another way that the international framework influences ocean investment is through voluntary agreements and principles by either private or public actors, or both. Examples include the Sustainable Blue Economy Financing Principles and the UN Global Compact Sustainable Ocean Principles, both aiming to increase financing for sustainable activities by coalescing pioneering actors, and the Poseidon Principles with a focus on decarbonising shipping (see Box 2). Another example of a private-sector initiative is the "Getting to Zero Coalition", with a particular focus on delivering zero-emission ships (IEA, 2020 [15]).

\section{National policy and regulatory aspects}

A strong national policy framework is fundamental to a strong investment environment in most sectors; this is no different for sustainable ocean finance. Such a framework helps establish expectations for investors, providing clear rules and predictability. National policy is also essential to ensure strong and coherent enforcement of laws, to be sure that sustainable practices are not undermined economically by illegal harmful activities. This however needs to be balanced to ensure that investment is not overburdened by bureaucratic "red tape". Similarly, and in particular for the ocean, a clear delineation of jurisdiction is essential within governments (either between government agencies, or between levels of government within a country), as well as internationally as discussed above.

Marine spatial planning (MSP) is a tool increasingly used to address competing demands for scarce ocean resources. IOC-UNESCO defines it as "a public process of analysing and allocating the spatial and temporal distribution of human activities in marine areas to achieve ecological, economic and social objectives that have been specified through a political process". As of August 2018, about 70 countries were preparing or had prepared 140 plans at the national, regional or local level (IOC-UNESCO, n.d.[28]). 
Marine protected areas (MPAs) can form an integral part of the MSP process, and can help in conserving fragile marine ecosystems and the services they provide. However, MPAs come in a variety of forms with varying degree of permissibility to potentially destructive practices, and therefore creating MPAs does not guarantee ocean protection - they must be effectively designed and implemented (OECD, 2017 $\left.7_{[6]}\right)$. The current international ambition is to achieve $10 \%$ marine protected area coverage by 2020 . The UN reports that as of December 2018, 17.2\% of areas under national jurisdiction were protected. In OECD countries, the proportion of MPAs has grown steadily and accounts for $21 \%$ of EEZ (OECD, 2020[10]) (Figure 3). In September 2019, the United Kingdom announced a global alliance committed to protected 30 percent of the global ocean to be protected by Marine Protected Areas by 2030 (Defra, 2019 [29]).

The connectivity of MPAs is also important, both to improve their effectiveness and to influence the sustainability of ocean sectors operating outside of, but between, different MPAs. This connectivity matters because ocean species are not, of course, constrained within the boundaries of MPAs. Well-developed and functionally connected MPA networks can provide added protection as they facilitate shifts of populations and ecosystem types across the ocean, as well as the movement of individuals in response to adverse impacts in one MPA including due to climate change impacts (OECD, 2017[6]).

From a sustainable investment perspective, marine spatial planning (MSP) accompanied by effective and sufficiently funded enforcement of protected areas, including networks of MPAs, can substantially improve the business case for investment in sustainable activities in those sectors that are dependent on ocean ecosystems (OECD, 2017 $\left.{ }_{[6]}\right)$.

Figure 3. Extent of Marine Protected Area coverage by country

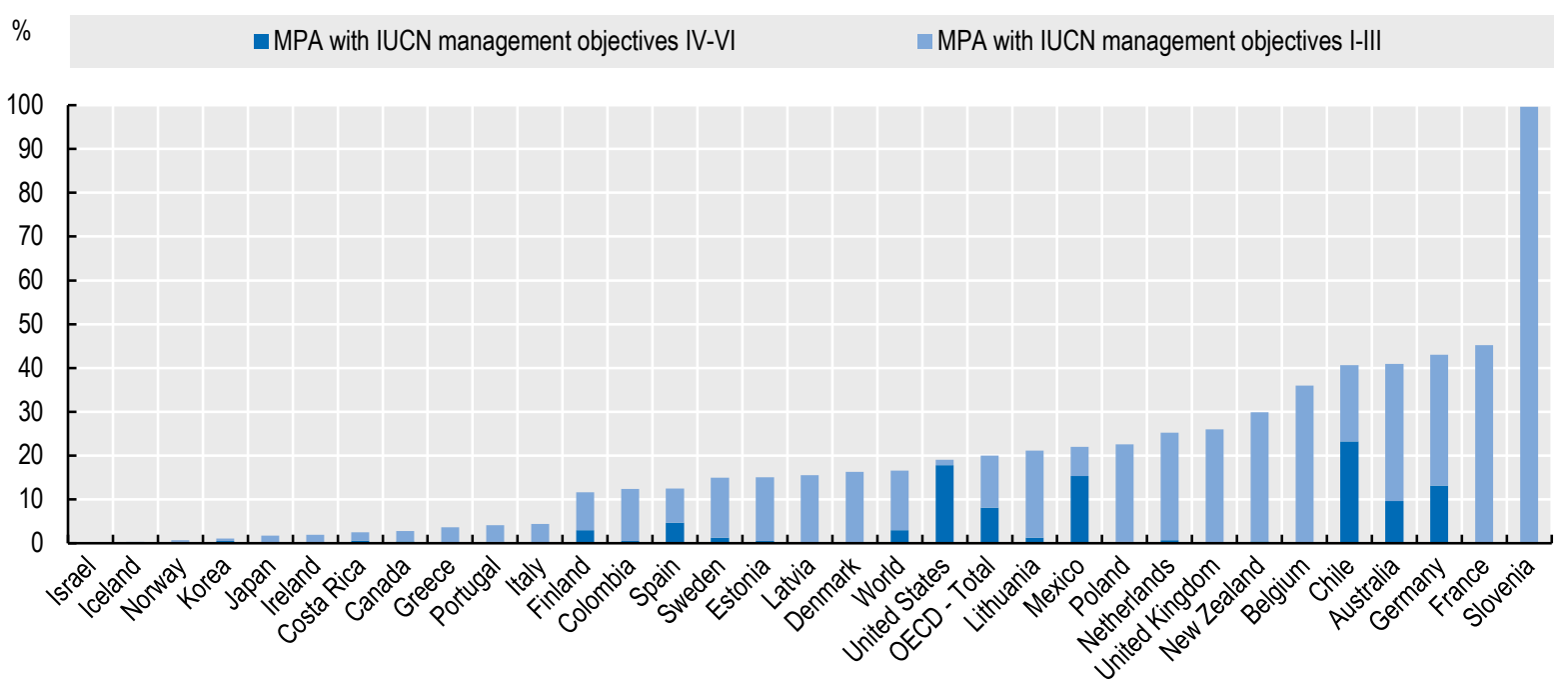

Note: Marine protected area designated with IUCN management objectives I-III, which generally preclude commercial fishing and other extractive industries, as share of exclusive economic zone. Marine protected area designated with IUCN management objectives IV-VI or with no management category provided, as share of exclusive economic zone.

Source: $\left(\mathrm{OECD}, 2020_{[10]}\right)$ 


\section{Economic instruments}

Policy measures that increase the cost of unsustainable activities or decrease the cost of sustainable activities can help to shift investment. For example, taxes, charges and fees can be used not only to raise revenues for governments but to send market signals that raise the price of unsustainable activities. Moreover, if the revenue is used to finance continued implementation and enforcement, the sustainability benefits can be even larger. Similarly, well-designed environmentally-motivated government subsidies can have important effects on improving the investment case for sustainable activities. The reverse is also true, whereby government support may directly or inadvertently encourage harmful activities.

While there has been some progress in strengthening economic instruments to incentivise ocean sustainability, there is significant scope to scale up. According to data reported to the OECD Policy Instruments for the Environment (PINE) database, to which more than 110 countries are currently contributing, 56 countries report using economic instruments targeted at ocean sustainability, a three-fold increase since 1980 (OECD, 2020 $\left.0_{[10]}\right)$.

Fees and charges, such as entrance fees to marine national parks, charges on sewage discharge into the ocean and fines for non-compliance, have been introduced in at least 24 countries (Figure 4). Over 40 countries report using ocean-related taxes - such as on fisheries, shipping and marine pollution - making them the most common economic policy instrument reported to the database. Among OECD countries, ocean-related tax revenue amounted to USD 4 billion in 2018, which represented less than $0.5 \%$ of the total Environmentally Related Tax Revenue (ERTR) in 2018 (OECD, 2020 $[10])$. This amount has been broadly stable since 2000 but accounts for a decreasing share of the total ERTR.

Tradeable permit systems are another form of economic instrument aiming to manage ocean resources or pollutants, whereby the government applies a total allowable limit and individual permits are traded in a market. While taxes form the largest proportion of oceanrelated economic policy instruments, tradable permits are highest in the ocean domain compared to other environmental domains $\left(\mathrm{OECD}, 2020_{[10]}\right)$. Examples include individual fishing quotas (ITQs), transferrable vessel quotas and territorial user rights.

Figure 4. Number of ocean sustainability-related policy instruments by type

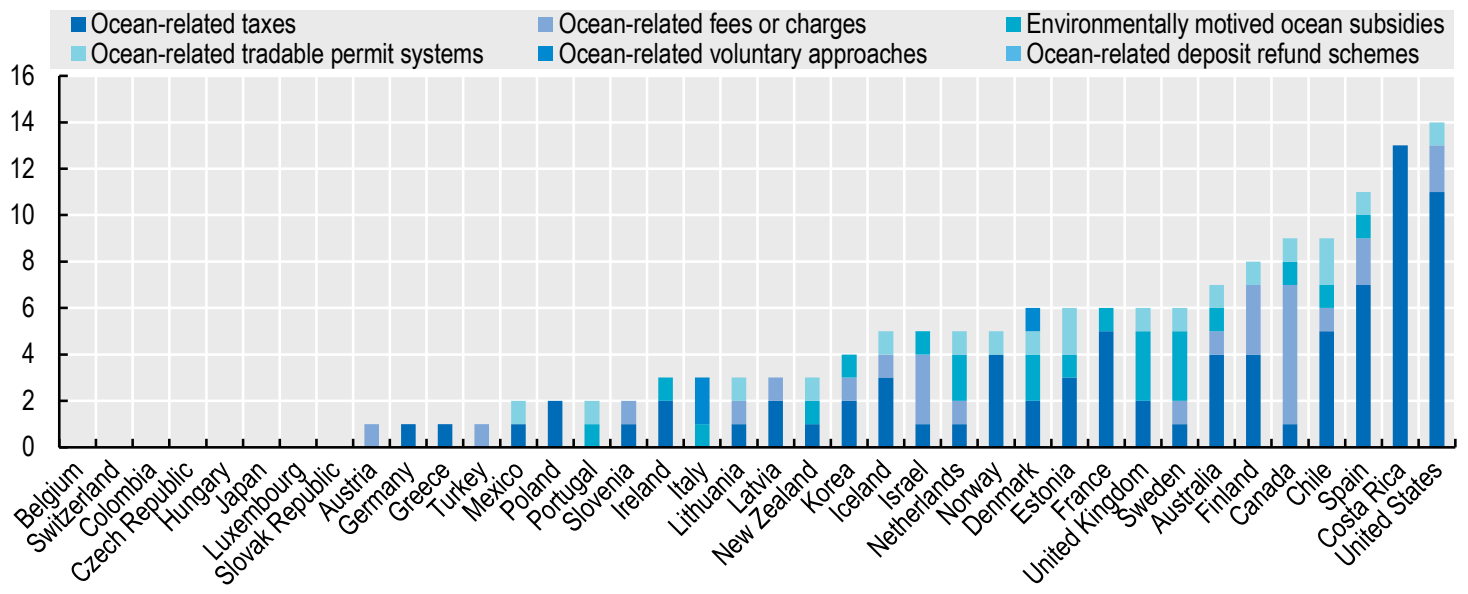

Source: $\left(\mathrm{OECD}, 2020_{[10]}\right)$ 
Subsidies and other public support measures can have a strong influence on the investment case for sustainable ocean activities. Targeted subsidies can be used to decrease the costs of sustainable activities. These environmentally-motivated subsidies - such as feed-in tariffs for offshore energy generation and conservation grants to protect marine biodiversity - have been reported in at least 19 countries $\left(\right.$ OECD, 2020 $\left.0_{[10]}\right) .^{5}$

Equally important to putting in place incentives that encourage sustainable activities is the need to phase out incentives that support unsustainable activities. Ocean-related fossil fuel support measures are in effect in 30 of the 42 countries covered by the OECD Inventory of Fossil Fuel Support Measures. Support by fossil-fuel producing countries includes preferential tax treatment for entities with offshore oil and gas extraction; research and exploration activities; port infrastructure upgrades for increased fossil fuel trade capacity; and capacity building on decommissioning activities. Countries that are primarily fossilfuel consumers allocate ocean-related support between the fisheries and aquaculture and the transportation sectors, for example with preferential tax rates on fuels for vessels $\left(\mathrm{OECD}, 2020_{[10]}\right)$.

In the case of fisheries, support that reduces the costs of inputs, such as fuel or vessel modernisation, can have negative impacts on sustainability. On the other hand, support that is partially de-coupled from fishing activities, such as income support and insurance systems, is both more beneficial to small-scale fishers and less harmful from a sustainability perspective $($ OECD, 2020 [30] $)$. There is significant scope to redirect support: 39 countries report to the OECD Fisheries Support Estimates database, and estimates that $69 \%$ of direct support for fisheries was spent to lower the costs of inputs (accounting for USD 3.2 billion annually on average over 2016-2018). OECD data shows support that is decoupled from fishing activities only accounted for $22 \%$ of direct support (OECD, 2020[31]).

\section{Standards}

Mandatory standards are command-and-control instruments that dictate requirements to be met. They can help create a clear signal for economic actors to take action to become more sustainable users, or face fines and other penalties for non-compliance. This is turn can affect non-compliant companies' access to finance. Mandatory standards exist for fishing gear, quotas on fish catch, commercial fishing permits, emission standards for waterway engines, fuel sulphur limits for vessels, among many others. In shipping for example, the MARPOL convention stipulates mandatory international standards, including global regulations on energy efficiency standards were introduced for shipping in 2013, to help reduce the industry's air pollution and carbon emissions (IMO, n.d.[27]).

Voluntary standards, such as sustainability certification for seafood products (whether independent or government-run), are also well-established in ocean industries. They aim to create demand and potentially price premiums for products with certified supply chains. This can create incentives to improve practices, again with implications for access to finance if investors turn increasingly to companies engaged with certified supply chains. Many such standards exists; some are international, such as the Marine and Aquaculture Stewardship Councils (MSC and ASC), whereas others are specific to particular brands or countries. Given the multiplication of such schemes, and challenges about the overall

5 OECD countries reporting environmentally-motivated subsidies to OECD PINE database: Australia, Canada, Chile, Denmark, Estonia, France, Ireland, Israel, Italy, Korea, Netherlands, New Zealand, Portugal, Spain, Sweden, United Kingdom. Non-OECD countries reporting environmentally-motivated subsidies to OECD PINE database: Argentina, India, Indonesia. 
effectiveness and credibility of some labels, several initiatives have been launched to improve standards and comparability (Prag, Lyon and Russillo, 2016 ${ }_{[32]}$ ) (Global Sustainable Seafood Initiative, 2019[33]). Technical innovation for supply chain transparency can have an important positive impact on the use of such standards, as discussed in the next section.

\section{Transparency and disclosure of financial information}

Transparency of data on performance, risks and opportunities are needed to help guide investors towards activities in support of a sustainable ocean. Disclosing information regarding the potential climate, biodiversity, plastic pollution or other environmental impacts from potential investments is key to better understand risk. A dearth of consistent and comparable data on environmental impacts, and likewise a lack of information of the supply of and demand for long-term finance, can hinder investment and policy decisions. The wide range of economic activity deployed in relation to the ocean requires an equally robust and complex understanding of the impacts of these activities. Extensive learning can be gleaned from the climate finance sphere, including with respect to transparency (see section above). For example, the Task Force on Climate-related Financial Disclosures (TCFD) and the newly-launched Task Force on Nature-related Financial Disclosures (TNFD) can provide strong vehicles to encourage disclosure for ocean-related activities.

Recent work on enhancing ocean-specific principles for sustainable investment - many of which call for greater transparency - can help to reorient finance towards more sustainable activities in the ocean economy (see Box 2). Many of these principles are voluntary; governments can play a role in encouraging or requiring, for example, adherence to disclosure guidelines, better subsidy reporting for harmful activities, providing preferential treatment to companies demonstrating higher standards of responsibility and encouraging stronger transparency through supply chains.

Supply-chain transparency can be particularly challenging in ocean sectors, given inadequate data and tracking. However, increasing consumer demand - for example, for sustainably-sourced seafood - can help drive transparency in supply chains. Advances in technology can help enhance supply chain transparency. For example, in 2018 WWFAustralia and BCG Digital Ventures launched a platform called OpenSC, which uses blockchain technology to help reduce IUU fishing and the use of slave labour in Pacific Islands' tuna industry (WWF, 2018[34]). By scanning the tuna packaging using a smartphone app, the consumer will be able to find out where and when the fish was caught, by which vessel and by what fishing method. FishCoin provides another example, using Blockchain-based traceability to reward fisheries for data gathering and passes the cost further up the supply chain, to stakeholders such as grocery stores and restaurants who gain to profit from higher levels of seafood traceability (Fishcoin, n.d.[35]). With this information about each step of the supply chain readily available, investors can avoid exposure to supply-chain risks.

\section{Creating conditions for accelerated innovation}

Innovation is essential to not only enhance knowledge and understanding of marine ecosystems but also to deliver new technologies for improving the sustainability of oceanbased industries. This combination has the potential to create win-win solutions, by both enhancing economic performance while conserving and sustainably using ecosystems and their services $\left(\right.$ OECD, 2019 $\left.9_{[36]}\right)$. For example, advancements in wind energy technology, plastic alternatives or alternative fish proteins can provide solutions to many of the social 
and environmental challenges facing the ocean. Deriving feed for aquaculture from wildcapture forage fish is increasingly unsustainable. Innovative alternatives include farmed insect protein, lab-grown protein and food waste (Hua et al., 2019 [37] $)$. In general, effective technological innovations need not be complex. For example, hook pods and bird scaring lines have been successful in greatly reducing albatross by-catch in fisheries (Maree et al., $\left.2014_{[38]}\right)$

The work of innovation is inherently risky and uncertain, with potential for pay-off but also for failure. Governments have an important role to play in supporting innovation that goes beyond funding R\&D through, for example, funding for innovation networks that can help to de-risk innovation and encourage greater private finance innovation investment (OECD/The World Bank/UN Environment, 2018[39]).

Public funding for R\&D is nevertheless still an important driver of innovation, and COVID19 recovery policies present an opportunity to increase innovation as part of economic recovery. Public funding for ocean-related renewable energy R\&D - including tidal, wave, salinity gradient and offshore wind energy - increased sharply since 2008, but remains relatively modest as a share of total energy RD\&D, at under USD 200 million in 2018 and about $1 \%$ on average across OECD countries, with no clear overall trend in recent years. Technological innovation measured by the number of patent applications directed at ocean sustainability - in particular renewable energy, pollution control and climate change technologies in maritime transport, and mitigation and adaptation technologies in fisheries and aquaculture - has doubled worldwide since 2000 and is concentrated in OECD countries, particularly United States, Korea and Japan (OECD, 2020 $\left.0_{[10]}\right)$.

\section{Data and monitoring}

Innovation is also required in how the ocean, and the economic services it provides, are valued and accounted for. For sectors that depend on ocean ecosystems, a comprehensive understanding of the value of biodiversity and its ecosystem services is fundamental to scale up sustainable ocean finance. This would allow more appropriate valuation of nonfinancial assets, and in turn economic activities that can either harm or help protect these services. Sufficiently valuing the current and future value of ecosystems is to successfully scale up many of the financial instruments described above. For example, better valuation can make for a more compelling case in favour of ecosystem restoration projects. There is already evidence that benefits of restoration can far exceed the costs, in particular for coastal wetlands. The estimated annual value of seagrass nutrient cycling is estimated at USD 1.9 trillion annually - approximately equal to Canada's GDP in 2019 (OECD, $\left.2020_{[40]}\right)$ - and coral reef tourism alone is valued at USD 36 billion (OECD, 2019 ${ }_{[41]}$ ). Additionally, improved understanding in the links between MPAs and how they are connected could improve both effectiveness of MPAs and allow for better targeting of incentives for industries operating outside of MPAs.

However, valuing marine biodiversity and ecosystems is complex, relying on biophysical and economic assessments that are currently not possible or not undertaken in much of the world, though such valuations have been increasing over time (OECD, 2017 $\left.{ }_{[6]}\right)$. Some countries have started to make progress, including through national ecosystem assessments that include marine and coastal ecosystems. 


\section{Financing instruments and investment models}

Public finance can be used to directly fund sustainable investments as well as to help redirect private finance towards sustainable businesses and activities, including through blended finance and risk-sharing arrangements, as well as supporting new and redesigned financial instruments that mobilise private capital for sustainable ocean activities (OECD, $\left.2020_{[9]}\right)$. This section briefly introduces the types of investment models and tools that can be used to increase mobilisation of private capital for ocean activities, including revenue enhancements and risk mitigation. A more detailed discussion of the 'market size' of these financing instruments and mechanisms and the opportunities and challenges to scale them up can be found in (OECD, 2020 $\left.{ }_{[9]}\right)$. This selection is by no means exhaustive and other instruments and investment models, in particular at smaller scales, can be essential sources of finance for smaller businesses and small holders (such as microfinance debt and revolving loan funds, and crowd-sourced equity, described for example in (Friends of Ocean Action, 2020[7])).

\section{Blended finance arrangements}

The OECD estimates that, through blended finance arrangements, ODA leveraged a total of USD 2.96 billion of private finance in support of ocean-related projects in 2013-17, equivalent to an annual average of USD 593 million (OECD, 2020 $[9]$ ). Private finance was mobilised both for ocean-based industries and ecosystems (USD 1.3 billion, or 44\%) as well as for land-based activities that reduce negative impacts on the ocean, such as waste management, sanitation and water treatment (USD 1.7 billion, or 56\%). A number of leveraging ODA instruments were employed, from simple ODA grants to standard ODA loans as well as guarantees, syndicated loans, etc. These instruments were used to de-risk investments or structure returns so as to improve the commercial viability of investments. Upper middle-income countries (UMICs) benefited the most in 2013-17 from the leveraging effect of development finance instruments, receiving $39 \%$ of the overall amounts mobilised, mainly in South America.

While blended finance can help mobilise additional finance towards sustainable ocean economies in developing countries, not all blended finance is quality blended finance. Blended finance needs to be anchored to a development rationale, tailored to the local context and be monitored and evaluated for its development contribution, as per the OECD DAC Blended Finance Principles mandate (OECD, 2018 $\left.{ }_{[42]}\right)$. Further, rather than become a permanent feature in private investments, it should be a time-bound intervention aimed at spurring the replication of similar projects via demonstration effects and build new sustainable markets and products.

ODA has also been at the core of the development of a range of new financial products and mechanisms for ocean conservation and sustainable use (OECD, 2020 $\left.0_{[9]}\right)$, such as blue bonds, debt for nature swaps, and insurance schemes, discussed below. Development partners have supported the creation and implementation of new financial instruments and products in various ways, from contributing technical assistance and absorbing the costs of the development phase of these new instruments, to supporting the identification a pipeline of bankable projects, to providing concessional finance to improve the commercial investments viability and make projects more attractive by bringing down the risk-adjusted financing rate. 


\section{Payment for marine ecosystem services}

Payment for ecosystem services (PES) are a well-established policy instrument to promote sustainable use of terrestrial ecosystems, though they are now increasingly also used to promote ocean sustainability in some cases (OECD, 2017[6] $)$ (AXA XL, 2019[43]). PES are economic instruments that create a monetary flow from the beneficiaries of ecosystem services to those whose actions can enhance or protect those ecosystems. In other words, PES address market failure by compensating individuals or communities whose land use or other resource management decisions influence the provision of ecosystem services for the additional costs of providing these services. PES can be used to complement existing policy instruments, for example by incentivising enhancements of ecosystems over and above those required by existing regulatory instruments (OECD, 2010 $\left.0_{[44]}\right)$.

One area increasingly in the spotlight is monetising so-called "blue carbon" in coastal ecosystems. Coastal systems such as mangroves, salt marshes and seagrass meadows are estimated to hold more carbon per unit than their terrestrial counterparts and therefore provide tremendous value in combatting climate change (OECD, 2017 $\left.{ }_{[6]}\right)$. If these ecosystems are destroyed, their sequestered carbon is released into the atmosphere. By leveraging established carbon credit methodologies, the amount of GHG avoided by ecosystem protection can be quantified and purchased as a carbon offset, and the ecosystem service of climate regulation is at least partially compensated.

Protecting coastal systems in this way also brings substantial other benefits; for example, mangroves can serve as a natural barrier against flooding or cyclones, which is predicted to increase in many coastal communities as the planet warms, as well as increase fish catches by supporting vital habitats (Lau, 2013 ${ }_{[45]}$ ). These coastal protection and fishhatching services are therefore co-benefits derived from blue carbon payments, but are not directly compensated. The challenge, therefore, is to find ways to adequately compensate people whose livelihoods depend on mangrove exploitation, or who considerable destruction of mangrove to develop profitable aquaculture farms. This could be either by securing sufficiently robust prices through the carbon market - for example through price premiums for buyers who recognise the additional benefits - or to identify and charge beneficiaries of these other ecosystem services.

Where the benefits of ecosystem services accrue at different geographical scales, it can be difficult to design a PES scheme. The climate regulation service is global; providing key habitat for fisheries at certain points during their lifecycle before moving to a different habitat, is regional; and protection of communities from the effects of storm surges and flooding is local. Additionally, from a carbon market perspective, blue carbon schemes require particular methods and safeguards to convince buyers of the permanence of the stored carbon. Layering multiple buyers for overlapping ecosystem services that arise from the protection of the same parcel of ocean area can pool resources and create buy-in across a wider range of potential beneficiaries.

\section{Conservation Trust Funds}

Conservation trust funds (CTFs) are independent legal entities that bridge donors to implementing organisations by providing and sourcing capital specifically for conservation projects. While not a new concept, CTFs are being increasingly in the ocean context, such as providing sustainable financing for MPAs or PES schemes. Trust funds can include endowment funds, where only the interest from the fund is used for projects; sinking funds, where both the interest and the principle are used for financing projects until the fund is 
depleted; and revolving funds, where the fund is replenished on a regular basis through sources such as use fees or taxes.

Examples of conservation trust funds include the Banc d'Arguin and Coastal and Marine Biodiversity Trust Fund (BACoMaB) endowment fund, which was established in 2009 to finance the conservation of the Banc d'Arguin National Park and other Mauritanian coastal and marine protected areas. The fund was initially established with financing from the Government of Mauritania, the French Development Agency and the French Facility for Global Environment, and continues to finance the parks through the endowments income (OECD, 2017 $\left.7_{[46]}\right)$.

\section{Blue bonds and other debt instruments}

Bonds are debt-financing instruments, which can be issued by governments (at the national "sovereign" or subnational levels), development banks, and companies. Overall, bonds provide the backbone of the global capital markets. More specifically, project-based bonds can be attractive for certain projects as they provide low-cost, long-term sources of debt capital, and can tap into a deep global pool of capital with a diverse base of investors (OECD and Bloomberg Philanthropies, 2015 $[47]$ ). Blue bonds have recently risen to prominence and are primarily bonds where the use of proceeds is specifically earmarked for sustainable ocean uses, and can include both sovereign and corporate bonds.

In general blue bonds follow the model of more established green bonds which are earmarked specifically for climate or environmental projects; some consider "blue" bonds to be a sub-category of wider "green" bonds. Before the COVID-19 crisis, green bond issuance had been growing significantly, setting a new global record in 2019 at USD 257.7 billion and representing a 51\% growth relative to 2018 (Climate Bonds Initiative, 2019 [48]). The success of green bonds may demonstrate the potential for encouraging investment in sustainable ocean projects. Recognised principles and guidelines, including the Green Bond Principles and the Climate Bond Standards, have been developed to help define the green bond market and make it easier to investors to understand the relative "green credentials" of different bonds (OECD and Bloomberg Philanthropies, 2015 [47] $)$. As highlighted above, similar guidance could help establish the blue bond market as a viable investment vehicle to support sustainable ocean financing.

The first sovereign blue bond was launched in 2018 by the Seychelles, an archipelago nation in the Indian Ocean with heavy reliance on ocean industries including tourism and fisheries. The bond attracted private capital through three socially-responsible impact investors. However, the USD 15 million and 10-year bond. The bond was designed and implemented with the support of the international development community, including through credit enhancing provided by the World Bank Group and the Global Environment Facility (World Bank, 2018 $8_{[49]}$ ). The proceeds will support the expansion of marine protected areas to $30 \%$ of their EEZ, improved governance for priority fisheries, and development of the country's blue economy (World Bank, 2018 [50]).

While the blue bond market remains small, more issuances have started to appear. In 2019, the World Bank launched a Sustainable Development Bond to address marine plastic waste. The bond raised USD 10 million and is sold by Morgan Stanley (World Bank, 2019 [51]). The Nordic Investment Bank, the largest issuer of green bonds in the Nordic region, traded its first Nordic-Baltic Blue Bond in 2019. The 5-year and SEK 2 billion bond that will focus on wastewater treatment, prevention of water pollution and water-related climate change adaptation in the region (Nordic Investment Bank, 2019 ${ }_{[52]}$ ). Both the World Bank and NIB bonds were oversubscribed, suggesting high levels of interest from investors. 
Also in 2019, the Nature Conservancy unveiled plans to launch Blue Bonds for Conservation, a plan to mobilise USD 1.6 billion to protected 4 million square kilometres of the world's ocean over the next 5 years by supporting 20 island nations to refinance national debt (The Nature Conservancy, 2019 ${ }_{[53]}$ ). Asian Development Bank's (ADB) Oceans Financing Initiative, part of its USD 5 billion Healthy Oceans Action Plan, also aims to support developing countries through innovative instruments including blue bonds (ADB, 2019[54]).

Corporate blue bond issuance can help to raise finance for the private sector to increase investment in sustainable ocean initiatives. The UN Global Compact outlines two prerequisites to fulfil issuers' expectations. First, companies must ensuring a company strategy and activities are aligned with the SDGs. Second, the bond should be linked to key performance indicators (KPIs) that are transparent, measurable by a third party and subject to reporting to the issuer. The UN Global Compact has developed a framework based on five "tipping points" for a healthy and productive ocean based on the main ocean-related industrial activities, which can provide a starting point for developing blue bond KPIs. For example, activities related to the tipping point "sustainable and fully traceable seafood" may wish to attach a KPI such as ensuring that all fishery operations are MSC-certified (Sustainable Ocean Business Action Platform, 2020[55]).

Aside from issuing corporate bonds, many companies rely heavily on traditional bank loans to secure debt financing. Loan covenants tied to sustainability requirements, or other methods of making loans dependent on sustainability, could be an effective means for banks to encourage sustainability investments in ocean sectors. One recent study finds that such covenants could be particularly effective to influence investments in the fisheries sector, citing recent examples where interest rates are variable and dependent on sustainability performance. Unlike bonds, which are linked to specific projects, such loans can be used for general corporate purposes (Jouffray et al., 2019 $9_{[56]}$ ).

\section{National debt restructuring and swaps}

Costs associated with debt servicing can be a major burden for governments, particularly developing countries. National debt restructuring with an environment or sustainability goal, through for example debt-for-nature swaps, can be an effective means of using public finance to support both development - through the alleviation of public debt loads - and environment objectives. UNCTAD estimates that some developing countries allocate $25 \%$ or more of government revenue to debt servicing (UNCTAD, 2020 $0_{[57]}$ ). These servicing costs will only be exacerbated by the ongoing COVID-19 crisis, where countries worldwide are announcing historic stimulus packages, financed largely by borrowing.

National debt restructuring and debt swaps can present an opportunity to reduce a country's debt - thereby freeing revenues for present and future generations of citizens - while also serving to meet a goal that is determined to be mutually beneficial to both the country and the lender. To date, debt-for-nature swaps have led to approximately USD 1.8 billion owed by 21 low- and middle-income nations, which generated USD 400 million for conservation. Debt-for-nature swaps carried out by all other high-income nations totalled USD 1 billion of debt cancelled and generated about USD 500 million for conservation (Sommer, Restivo and Shandra, 2020 $0_{[58]}$.

While originally established for land-based conservation, this concept has recently gained traction in sustainable ocean finance. In 2016, the Government of the Seychelles and Paris Club creditors, supported by The Nature Conservancy, established the first debt conversion swap focused on climate adaptation to include a marine conservation component. The 
restructuring supports climate change adaptation in particular through conservation of coastal zones, coral reefs and mangroves. Through a combination of impact capital loans and grants, The Nature Conservancy bought back USD 21.6 million in Seychelles debt. The funds otherwise allocated to debt servicing are managed by the Seychelles Conservation and Climate Adaptation Trust (SeyCCAT), an independent, public-private fund (The Nature Conservancy, n.d.[59]). The funds are dedicated to three streams of work: on-the-ground conservation efforts (USD 5.6 million), paying back the loan (USD 15.2 million over ten years) and managing the Trust's endowment to further conservation efforts (USD 3 million). By March 2020, the swap had facilitated the conservation of 32\% of the Seychelles' EEZ (World Ocean Initiative, 2020[60] $)$.

\section{Insurance mechanisms}

The insurance sector can play several distinct roles in driving the sustainable use of ocean resources. One role is through limiting access to insurance for harmful actors. Insurers can make it difficult, costly or impossible to obtain insurance for activities or assets that are considered environmentally risky, that are linked to illegal practices in some way, or that will suffer in the face of a damaged environment. A separate role is through the influence of insurers as institutional investors. Yet another role is through the development of innovative insurance products, which can both encourage investment in regions or activities that are otherwise perceived as too risky (by improving insurance coverage and reducing premiums) and contribute to protection of essential ecosystems that are also important for resilience of coastal communities.

Shipping insurance has always been a notable and important component of the wider insurance industry. However, when looking more broadly across the ocean economy, insurance penetration is currently generally low, representing an opportunity to close the "coverage gap" - the gap between the amount of insurance needed and the amount of insurance provided. This is particularly the case in developing countries, where ocean livelihoods are increasingly threatened by climate change. Climate impacts are also, however, changing the risks that insurers themselves take on (Niehörster and Richard J. Murnane, 2018[61]).

Flood insurance can be used to help support communities as they face the risks of sea-level rise. They can result in lower costs to the public, flexible and efficient use of space and help ensure individuals are aware of coastal risks. For example, in the United States, insurance coverage through the public National Flood Insurance Program (NFIP) is only offered in communities that agree to implement a set of minimum NFIP floodplain development standards. While not always related to the ocean, these standards include the use of flood maps in development planning, requirements for a base flood elevation and building standards to ensure that new buildings will be protected. In addition, a Community Rating System has been established to provide insurance premium discounts to households in communities that adopt recognised flood risk management practices above those required by the NFIP (OECD, 2019 [62]).

Parametric insurance, or index-based insurance, has emerged as an insurance instrument to address climate challenges, and may become an increasingly relevant protection mechanism for the ocean economy. In contrast to traditional indemnity-based insurance, parametric insurance pay-outs are based on trigger events, such as an earthquake of a certain magnitude or sea-level rise of a certain amount, regardless of actual damage incurred. This allows the pay-out to be processed more quickly, without the initial burden 
of proof placed on the insured. Parametric insurance can be used to supplement damage incurred to subnational regions that is not otherwise covered by the national government or through other methods of insurance. Conversely, it also requires an understanding by the insured on the degree of damage that would be sustained through a trigger-level event; without such information, the insured may be left bearing the brunt of the damage even after compensation (Shayne C. Kavanagh and Elizabeth Fu, 2020 [63]).

Swiss Re, together with The Nature Conservancy and regional governments in Mexico, have joined forces to help protect the Mesoamerican coral reef. The reef is closely linked to the economic well-being of the region's important tourism industry, given its importance in preventing beach erosion. The insurance mechanism funds premiums by combining private capital with public resources in a trust. Following a storm, it can rapidly deploy funds to enable trained community members to address reef damage (Swiss RE, 2019[64]]).

The Caribbean Oceans and Aquaculture Sustainability Facility (COAST) insurance programme, the first parametric insurance for fisheries, provides such an example with pilot products for Saint Lucia and Grenada for the 2019-2020 policy year. Launched in July 2019, this programme was developed with financial support from the US State Department and led by the World Bank and the Caribbean Catastrophe Risk Insurance Facility (CCRIF) with The Caribbean Regional Fisheries Mechanism (CRFM). The insurance provides coverage for losses from adverse weather on fishers and for direct damages to fishing vessels and other equipment caused by cyclones (CCRIF-SPC and World Bank Group, 2019 [65]).

A recent development of note is the creation of the Ocean Risk and Resilience Action Alliance (ORRAA). The alliance is a multi-sector public-private collaboration with prominent involvement of the insurance company AXA XL. The aim is to leverage public and private finance to build coastal resilience in developing countries (in particular smallisland states) through research to better understand the ocean risk landscape, and financial products that incentivise investment in natural capital (ORRAA, n.d.[66]) Initiatives include improving the financial resilience and adaptive capacity of coastal communities to incentivise sustainable fishing practices; scaling coral reef insurance; and creating credit initiatives to give a "blue carbon" and resilience value to mangroves.

\section{Impact investing and dedicated ocean funds}

Impact investments are made with the objective of having positive, measurable social and environmental impact together with a financial return (Global Impact Investing Network, n.d.[67]). Impact investing targets a wide range of challenges, and has grown to attract a wide range of individual and institutional investors where the core objective of investing goes beyond solely maximising financial returns on investment.

Examples of impact investing are growing in support of sustainable ocean initiatives. For example, Bloomberg Philanthropies Vibrant Oceans Initiative was launched in 2014 with an initial commitment of USD 53 million and targeting 3 countries and focused on ensuring evidence-based conservation practices and implementing data-driven fisheries management policies. Phase II of the Initiative was launched in 2018 with a commitment of USD 86 million, targeting 10 countries that have priority coral geographies, are top fishing nations, or rely on fish as a major food source (Bloomberg Philanthropies, 2020 ${ }_{[68]}$ ).

Another example is Mirova's Althelia Sustainable Ocean Fund (SOF), which prioritises sustainable seafood, circular economy and ocean conservation. The Fund is focused $40 \%$ 
on projects in Latin America \& Caribbean, 30\% on Africa and 30\% on the Asia and Pacific region. The SOF is backed by a USD 50 million Development Credit Authority (DCA) facility from USAID, and has significant institutional investor backing including from the European Investment Bank, Axa Investment Managers and IADB (Althelia Funds, n.d.[69]). At its final closing in May 2020, the fund had reached USD 132 million in commitments (Institutional asset manager, 2020[70]).

Impact investors also played an important role in the landmark Seychelles blue bond described above. This highlights the trailblazing potential of impact investors to innovate and to demonstrate what is feasible in advance of investment and market conditions being favourable to full commercial capital investment. However, the scale of the ocean health challenge means a need for policy makers to set the conditions for a shift beyond impact investment to mainstream investors.

A notable bridge towards mainstream investment is the rapidly expanding universe of "Environmental, Social and Governance" (ESG) investing. Funds flowing into sustainable investment have grown steadily in recent years, and institutional investors with over USD 30 trillion of assets under management have pledged to use ESG investing. However, ocean sustainability has so far not been a major focus of ESG investment approaches (Reuters, $\left.2020_{[71]}\right)$. More generally, the wide variety of methodologies and standards being employed to rate investments, and the complexity of integrating all three pillars of ESG makes it challenging for investors to know if they are genuinely contributing to sustainability and therefore longer term better risk-adjusted returns (OECD, 2020 $\left.0_{[72]}\right)$. As both policy-driven and private sector initiatives seek to improve comparability of ESG approaches, there is a clear opportunity for greater inclusion and better characterisation of sustainable ocean investments.

\section{Box 2. Principles supporting sustainable ocean economy finance}

Principles guiding sustainable ocean finance and investment practices have emerged in the last few years. These principles are targeted towards helping investors and businesses channel finance towards activities in support of a sustainable ocean. In general, the principles are meant to complement existing green finance and investment principles.

The Sustainable Blue Economy Finance Principles represent the world's first global framework to finance a sustainable ocean economy. The European Commission, World Resources Institute (WRI), World Wildlife Fund (WWF) and the European Investment Bank (EIB) launched the Declaration at the 2018 Our Ocean conference. The Declaration calls on signatories to apply the 14 principles across their portfolios in order to unlock investment in sustainable ocean activities. They are intended to further the implementation of the Sustainable Development Goals (SDGs), in particular those contributing to Goal 14.

The UN Global Compact issued the Sustainable Ocean Principles in September 2019 that aim to provide a framework for responsible business practices in support of a healthy ocean. The 9 principles cover areas including ocean health and productivity, governance and engagement, and data and transparency. The principles have over 50 signatories to date, from a range of industries including food producers, financial services, energy, industrial transportation, and travel and leisure. 
The Principles for Investment in Sustainable Wild-Caught Fisheries, launched at the World Ocean Summit in 2018, aim at focusing investment in more sustainable wild-caught fisheries practices. It is accompanied by a scorecard whereby fisheries can be measured against a set of indicators linked to each of the 9 principles. The principles include elements of regulatory compliance, monitoring and enforcement; environmental status; traceability and transparency; human rights; and stakeholder engagement and access.

The Poseidon Principles are a global framework for financial institutions to assess and disclose the climate alignment of their shipping portfolios. The four principles are consistency with the International Maritime Organization's ambition to reduce GHG emissions by at least $50 \%$ by 2050 relative to 2008 levels. 18 financial institutions are signatory to the principles, representing USD 150 billion in shipping finance and more than a third of the global ship finance portfolio.

The International Finance Corporation's (IFC) Performance Standard 6: Biodiversity Conservation and Sustainable Management of Living Natural Resources is one of 8 performance standards designed to be applied throughout the life of an IFC investment. This performance standard recognises that biodiversity and its ecosystem services including marine biodiversity - are necessary for sustainable development.

Sources: (European Commission et al., 2018[73]) (UN Global Compact, 2019[74]) (Fitzgerald et al., 2019 ${ }_{[75]}$ ) (Poseidon Principles, n.d.[76] $)\left(\right.$ IFC, 2012 ${ }_{[77]}$ )

\section{Conclusions}

Conserving and sustainably using the ocean, seas and marine resources has become a global necessity for safeguarding future growth and prosperity alongside, and intertwined with, the fight against biodiversity loss and climate change. As economies and communities reel from the impacts of the COVID-19 pandemic, the vulnerability of societies and the natural capital they rely on has never been more pronounced. The stimulus packages governments are preparing provide an opportunity to reorient national policy objectives towards more sustainable outcomes. The ocean, as one of the world's main life-support systems, needs to feature prominently in these plans. Improved ocean sustainability is essential for longer-term growth and resilience.

It is increasingly clear that the ocean economy's long-term economic and societal potential cannot be fully realised unless more ambitious and effective measures are put in place to improve the conservation and sustainable use of the ocean at local, regional, national and international levels. This will require significant investment in new and systemic thinking across the board - in finance, innovation and technology, infrastructure, institutional co-operation, decision making processes, and the policy mix and governance arrangements that governments implement in supporting and encouraging effective ocean management.

Scaling up financing for new sustainable ocean activities is essential but not sufficient. The established ocean economy is large and in many cases both harmful to ocean health and not sustainable for the long-term. A concerted reallocation of capital away from potentially harmful to sustainable activities is also important, while protecting jobs and livelihoods. Creating the conditions for a major shift of private sector capital towards sustainability is needed. However, many investors and financial actors remain unaware of their portfolios' existing ocean impacts and unsure where potential investment opportunities lie, despite new awareness of the urgency of improving ocean sustainability globally. 
The reasons for the dominant share of financing currently flowing to unsustainable activities are varied, because the industries involved - and the impacts they have on the ocean - are also diverse. Defining what is "sustainable" - and not sustainable - differs across ocean sectors, meaning that the policy tools, regulation and financial instruments needed to make sustainable activities competitive and investable are also very varied. Nevertheless some commonalities can be identified, such as insufficient valuation of both the costs of environmental impacts, and the benefits provided by ocean ecosystems, now and in the future.

Developing countries - their fish populations, coasts and tourism, food security, and livelihoods often suffer the greatest consequences from global investments in unsustainable ocean economic activities. Therefore, international development co-operation has a critical role to ensure that sustainability is integrated in traditional financial services and investments, in financial markets (e.g. stocks and bonds), and in credit markets (e.g. loans or bonds). This will require supporting policies, regulations and financial levers for shifting finance from harmful and unsustainable practices to sustainable activities as well as supporting adequate representation of developing countries in key international processes and negotiations linked to ocean use (OECD, 2020 $\left.0_{[9]}\right)$.

Public policies and finance need to be consistent and commensurate with the need to align private finance to the sustainability imperative of the global ocean economy, and can do this in three main ways. First, by setting the policy framework and investment conditions that favour sustainability and act to align incentives and improve enforcement and traceability. Second, by contributing directly to funding sustainable activities, in particular those targeting ocean conservation and use, whether at home or through overseas development assistance. Third, through the employment of public finance to improve the risk and return profile of investments, for instance through blended finance arrangements and through creating and supporting new financing instruments. Blended finance needs to make a clear contribution to sustainability, aiming to change the market and craft new, more environmentally and socially sustainable business models and products in ocean-based sectors, rather than being a permanent feature in private investments. New financing instruments are required, including refined mechanisms to compensate ecosystem services, novel insurance mechanisms, new debt instruments such as blue bonds and sustainability linked loans.

Ultimately, successfully reversing ocean degradation and protecting the essential ecosystem services that the ocean provides will require a broader transformational shift across the finance sector. While better ocean regulation, targeted incentives and innovative financial instruments are all important parts of the equation, they need to be accompanied by a wider "resetting" of the financial sector that overcomes short-termism and fully values the material benefits of averting global environmental crises spanning, the ocean, terrestrial biodiversity loss and climate change. 


\section{References}

ADB (2019), ADB Financing Ambitious Climate Action in Asia and the Pacific.

Althelia Funds (n.d.), Sustainable Ocean Fund, https://althelia.com/sustainable-ocean-fund/ (accessed on 6 July 2020).

AXA XL (2019), A Blue Carbon future: How innovative thinking aims to increase coastal resilience and meet climate targets, https://axaxl.com/fast-fast-forward/articles/a-blue-carbonfuture-how-innovative-thinking-aims-to-increase-coastal-resilience-and-meet-climate-targets (accessed on 24 June 2020).

Bloomberg Philanthropies (2020), Vibrant Oceans, https://www.bloomberg.org/program/environment/vibrant-oceans/\#overview (accessed on 6 July 2020).

CCRIF-SPC and World Bank Group (2019), Caribbean Oceans and Aquaculture Sustainability FaciliTy: Making the fisheries sector in the Caribbean resilient to climate events.

Chami, R. et al. (2019), Nature's Solution to Climate Change, Finance and Development, https://www.imf.org/external/pubs/ft/fandd/2019/12/natures-solution-to-climate-changechami.htm.

CIESIN (2012), "National Aggregates of Geospatial Data Collection: Population, Landscape, And Climate Estimates, Version 3 (PLACE III).", Palisades, NY: NASA Socioeconomic Data and Applications Center (SEDAC)., http://dx.doi.org/10.7927/H4F769GP.

Climate Bonds Initiative (2019), 2019 Green Bond Market Summary, https://www.climatebonds.net/files/files/climate-resilience-principles- (accessed on 24 June 2020).

Defra (2019), UK creates global alliance to help protect the world's ocean, https://www.gov.uk/government/news/uk-creates-global-alliance-to-help-protect-the-worldsocean (accessed on 7 July 2020).

Dempsey, J. and D. Suarez (2016), “Arrested Development? The Promises and Paradoxes of "Selling Nature to Save It"”, Annals of the American Association of Geographers, Vol. 106/3, pp. 653-671, http://dx.doi.org/10.1080/24694452.2016.1140018.

European Commission et al. (2018), Declaration of the Sustainable Blue Economy Finance Principles, https://openknowledge.worldbank. (accessed on 25 June 2020).

FAO (2020), The State of World Fisheries and Aquaculture 2020, FAO, http://dx.doi.org/10.4060/ca9229en.

FAO (2017), Common Oceans ABNJ - Global sustainable fisheries management and biodiversity conservation in the areas beyond national jurisdiction. 
FAO (2007), “The world's mangroves 1980-2005”, FAO Forestry Paper, No. 153, FAO, Rome, http://www.fao.org/3/a1427e/a1427e00.pdf (accessed on 8 July 2020).

Fishcoin (n.d.), Fishcoin: Blockchain Based Seafood Traceability \& Data Ecosystem, https://fishcoin.co/ (accessed on 18 September 2020).

Fitzgerald, T. et al. (2019), Principles for Investment in Sustainable Wild-Caught Fisheries, http://www.fisheriesprinciples.org/files/2019/05/updated-PrinciplesInvestmentWEB final.pdf (accessed on 25 June 2020).

Friends of Ocean Action (2020), The Ocean Finance Handbook: Increasing finance for a healthy ocean, http://www3.weforum.org/docs/WEF FOA The Ocean Finance Handbook April 2020.pdf (accessed on 24 September 2020).

Fritsch, D. (2020), Investors and the Blue Economy, Credit Suisse, London, https://www.esgdata.com/blue-economy.

Global Impact Investing Network (n.d.), What You Need to Know about Impact Investing, https://thegiin.org/impact-investing/need-to-know/\#what-is-impact-investing (accessed on 6 July 2020).

Global Sustainable Seafood Initiative (2019), MORE SUSTAINABLE SEAFOOD FOR EVERYONE, http://www.ourgssi.org (accessed on 4 August 2020).

Hoegh-Guldberg, O. (2015), Reviving the Ocean Economy: the case for action - 2015, WWF International, Geneva, http://ocean.panda.org (accessed on 24 June 2020).

Hua, K. et al. (2019), "The Future of Aquatic Protein: Implications for Protein Sources in Aquaculture Diets", One Earth, Vol. 1/3, pp. 316-329, http://dx.doi.org/10.1016/j.oneear.2019.10.018.

ICCT, I. (2019), Silent but deadly: The case of shipping emissions | International Council on Clean Transportation, https://theicct.org/blog/staff/silent-deadly-case-shipping-emissions.

IEA (2020), International Shipping - Analysis - IEA, International Shipping Analysis, https://www.iea.org/reports/international-shipping.

IFC (2012), Performance Standard 6: Biodiversity Conservation and Sustainable Management of Living Natural Resources.

IMO (n.d.), Energy Efficiency Measures, http://www.imo.org/en/OurWork/Environment/PollutionPrevention/AirPollution/Pages/Techn ical-and-Operational-Measures.aspx (accessed on 6 July 2020).

Institutional asset manager (2020), Mirova 's Sustainable Ocean Fund holds final close at USD $132 \mathrm{~m}$, https://www.institutionalassetmanager.co.uk/2020/08/05/288267/mirovas-sustainableocean-fund-holds-final-close-usd132m (accessed on 21 September 2020). 
IOC-UNESCO (n.d.), Status of MSP, http://msp.ioc-unesco.org/worldapplications/status_of msp/(accessed on 7 July 2020).

IPBES (2019), Summary for policymakers of the global assessment report on biodiversity and ecosystem services of the Intergovernmental Science-Policy Platform on Biodiversity and Ecosystem Services Overall review editors, IPBES Secretariat, Bonn, https://www.ipbes.net/system/tdf/ipbes 7 10 add-1_advance 0. pdf?file $=1 \&$ type $=$ node $\&$ id $=35245$ (accessed on 10 July 2019$)$.

IPCC (2019), "Summary for Policymakers", in H.-O. Pörtner et al. (eds.), IPCC Special Report on the Ocean and Cryosphere in a Changing Climate, https://www.ipcc.ch/site/assets/uploads/sites/3/2019/11/03 SROCC SPM FINAL.pdf (accessed on 8 July 2020).

Jambeck, J. et al. (2015), "Plastic waste inputs from land into the ocean", Science, Vol. 347/6223, pp. 768-771, http://dx.doi.org/10.1126/science.1260352.

Jouffray, J. et al. (2019), "Leverage points in the financial sector for seafood sustainability", Science Advances, Vol. 5/10, p. eaax3324, http://dx.doi.org/10.1126/sciadv.aax3324.

Konar, M. and H. Ding (2020), A Sustainable Ocean Economy for 2050: Approximating Its Benefits and Costs Secretariat of the High Level Panel for a Sustainable Ocean Economy, World Resources Institute, https://oceanpanel.org/sites/default/files/202007/Ocean\%20Panel Economic\%20Analysis FINAL.pdf.

Lau, W. (2013), "Beyond carbon: Conceptualizing payments for ecosystem services in blue forests on carbon and other marine and coastal ecosystem services", Ocean and Coastal Management, Vol. 83, pp. 5-14, http://dx.doi.org/10.1016/j.ocecoaman.2012.03.011.

Maree, B. et al. (2014), "Significant reductions in mortality of threatened seabirds in a South African trawl fishery", Animal Conservation, Vol. 17/6, pp. 520-529, http://dx.doi.org/10.1111/acv.12126.

Martini, R. and J. Innes (2018), "Relative Effects of Fisheries Support Policies", OECD Food, Agriculture and Fisheries Papers, No. 115, OECD Publishing, Paris, https://dx.doi.org/10.1787/bd9b0dc3-en.

Millennium Ecosystem Assessment (2005), Ecosystems and Human Well-being: Wetlands and Water Synthesis.

Niehörster, F. and Richard J. Murnane (2018), Ocean Risk and the Insurance Industry, XL Catlin Services SE, UK.

Nordic Investment Bank (2019), Nordic Investment Bank - NIB issues first Nordic-Baltic Blue Bond, https://www.nib.int/who we are/news and media/news press releases/3170/nib issues first _nordic-baltic_blue_bond (accessed on 24 June 2020).

OECD (2020), 2020 Review of Fisheries (forthcoming). 
OECD (2020), Developing Sustainable Finance Definitions and Taxonomies, Green Finance and Investment, OECD Publishing, Paris, https://dx.doi.org/10.1787/134a2dbe-en.

OECD (2020), Environment at a Glance Indicators, OECD Publishing, Paris, https://dx.doi.org/10.1787/ac4b8b89-en.

OECD (2020), Fisheries support (indicator), https://dx.doi.org/10.1787/1ff7e544-en (accessed on 2 October 2020).

OECD (2020), GDP and spending - Gross domestic product (GDP) - OECD Data, https://data.oecd.org/gdp/gross-domestic-product-gdp.htm (accessed on 24 June 2020).

OECD (2020), OECD Business and Finance Outlook 2020: Sustainable and Resilient Finance, OECD Publishing, Paris, https://dx.doi.org/10.1787/eb61fd29-en.

OECD (2020), Sustainable Ocean for All: Harnessing the Benefits of Sustainable Ocean Economies for Developing Countries, The Development Dimension, OECD Publishing, Paris, https://dx.doi.org/10.1787/bede6513-en.

OECD (2019), Biodiversity: Finance and the Economic and Business Case for Action, OECD Publishing, Paris, https://dx.doi.org/10.1787/a3147942-en.

OECD (2019), Responding to Rising Seas: OECD Country Approaches to Tackling Coastal Risks, OECD Publishing, Paris, https://dx.doi.org/10.1787/9789264312487-en.

OECD (2019), Rethinking Innovation for a Sustainable Ocean Economy, OECD Publishing, Paris, https://dx.doi.org/10.1787/9789264311053-en.

OECD (2018), Human Acceleration of the Nitrogen Cycle: Managing Risks and Uncertainty, OECD Publishing, Paris, https://dx.doi.org/10.1787/9789264307438-en.

OECD (2018), OECD DAC BLENDED FINANCE PRINCIPLES for Unlocking Commercial Finance for the Sustainable Development Goals, http://www.oecd.org/dac/financingsustainable-development/development-finance-topics/OECD-Blended-Finance-Principles.pdf (accessed on 4 October 2020).

OECD (2017), Marine Protected Areas: Economics, Management and Effective Policy Mixes, OECD Publishing, Paris, https://dx.doi.org/10.1787/9789264276208-en.

OECD (2017), The Political Economy of Biodiversity Policy Reform, OECD Publishing, Paris, https://dx.doi.org/10.1787/9789264269545-en.

OECD (2016), The Ocean Economy in 2030, OECD Publishing, Paris, https://dx.doi.org/10.1787/9789264251724-en.

OECD (2010), Paying for Biodiversity: Enhancing the cost-effectiveness of Payments for ecosystem services, OECD Publishing, Paris, http://www.oecd.org/publishing (accessed on 24 June 2020). 
OECD and Bloomberg Philanthropies (2015), Green bonds: Mobilising the debt capital markets for a low-carbon transition.

OECD/The World Bank/UN Environment (2018), Financing Climate Futures: Rethinking Infrastructure, OECD Publishing, Paris, https://dx.doi.org/10.1787/9789264308114-en.

ORRAA (n.d.), ORRAA - Ocean Risk Alliance, https://www.oceanriskalliance.org/about/orraa/ (accessed on 3 July 2020).

Poseidon Principles (n.d.), A global framework for responsible ship finance, https://www.poseidonprinciples.org/about/ (accessed on 7 July 2020).

Prag, A., T. Lyon and A. Russillo (2016), "Multiplication of Environmental Labelling and Information Schemes (ELIS): Implications for Environment and Trade", OECD Environment Working Papers, No. 106, OECD Publishing, Paris, https://dx.doi.org/10.1787/5jm0p33z27wf-en.

Reuters (2020), "ESG investors slow to make waves in the \$2.5tn ocean economy | Reuters Events | Sustainable Business", https://www.reutersevents.com/sustainability/esg-investorsslow-make-waves-25tn-ocean-economy (accessed on 15 September 2020).

Shayne C. Kavanagh and Elizabeth Fu (2020), Parametric Insurance: An Emerging Tool for Financial Risk Management, Government Finance Officers Association, http://www.gfoa.org/research-reports (accessed on 24 June 2020).

Sommer, J., M. Restivo and J. Shandra (2020), "The United States, Bilateral Debt-for-Nature Swaps, and Forest Loss: A Cross-National Analysis", The Journal of Development Studies, Vol. 56/4, pp. 748-764, http://dx.doi.org/10.1080/00220388.2018.1563683.

Steffen, W., J. Rockström and K. Richar (2018), "Trajectories of the Earth System in the Anthropocene", Vol. 33/115, pp. 8252-8259, https://doi.org/10.1073/pnas.1810141115.

Sustainable Ocean Business Action Platform (2020), Blue Bonds: Reference paper for investments accelerating sustainable ocean business, https://unglobalcompact.org/library/5741 (accessed on 6 July 2020).

Swiss RE (2019), Designing a new type of insurance to protect the coral reefs, economies and the planet, https://www.swissre.com/our-business/public-sector-solutions/thoughtleadership/new-type-of-insurance-to-protect-coral-reefs-economies.html (accessed on 24 June 2020).

The Nature Conservancy (2019), An Audacious Plan to Save the World's Oceans, https://www.nature.org/en-us/what-we-do/our-insights/perspectives/an-audacious-plan-tosave-the-worlds-oceans/ (accessed on 24 June 2020).

The Nature Conservancy (n.d.), Debt Conversions for Marine Conservation and Climate Adaptation, https://www.nature.org/en-us/about-us/who-we-are/how-we-work/financeinvesting/naturevest/ocean-protection/ (accessed on 6 July 2020). 
UN Global Compact (2019), "Sustainable Ocean Principles", https://d306pr3pise04h.cloudfront.net/docs/publications\%2FSustainable+Ocean+Principles.pd f.

UNCTAD (2020), From the Great Lockdown to the Great Meltdown: Developing Country Debt in the Time of Covid-19, https://unctad.org/en/PublicationsLibrary/gdsinf2020d3 en.pdf?user=1653.

UNEP (2014), Valuing Plastics: The Business Case for Measuring, Managing and Disclosing Plastic Use in the Consumer Goods Industry, http://wedocs.unep.org/handle/20.500.11822/9238 (accessed on 9 July 2019).

World Bank (2019), World Bank Launched Bonds to Highlight the Challenge of Plastic Waste in Oceans, https://www.worldbank.org/en/news/press-release/2019/04/03/world-bank-launchesbonds-to-highlight-the-challenge-of-plastic-waste-in-oceans\# (accessed on 24 June 2020).

World Bank (2018), Seychelles launches World's First Sovereign Blue Bond, https://www.worldbank.org/en/news/press-release/2018/10/29/seychelles-launches-worldsfirst-sovereign-blue-bond (accessed on 24 June 2020).

World Bank (2018), Sovereign Blue Bond Issuance: Frequently Asked Questions, https://www.worldbank.org/en/news/feature/2018/10/29/sovereign-blue-bond-issuancefrequently-asked-questions (accessed on 24 June 2020).

World Ocean Initiative (2020), Seychelles swaps debt for nature, https://www.woi.economist.com/seychelles-swaps-debt-for-nature/ (accessed on 6 July 2020).

WWF (2019), VALUE AT RISK IN THE BLUE ECONOMY: Piloting a Systems Modeling Approach to Explore Sustainability Pressures and Financial Risk, https://wwfeu.awsassets.panda.org/downloads/metabolic wwf value at risk in the blue ec onomy 29112019 1r.pdf (accessed on 24 September 2020).

WWF (2018), How blockchain and a smartphone can stamp out illegal fishing and slavery in the tuna industry, https://www.wwf.org.au/news/news/2018/how-blockchain-and-a-smartphonecan-stamp-out-illegal-fishing-and-slavery-in-the-tuna-industry\#gs.9n00yf (accessed on 7 July 2020). 


\title{
Reframing Financing and Investment for a Sustainable Ocean Economy
}

This paper sets out a new framing of the challenges and opportunities for scaling up financing and investment for a sustainable ocean economy. It examines the particular challenges associated with financing sustainable ocean activities across different sectors and explores promising financing instruments, including by identifying learnings from elsewhere in the green finance sphere.

This paper contributes to the OECD horizontal ocean project. To support government efforts to transition to a more sustainable ocean economy, the OECD is mobilising expertise across multiple policy fronts, covering environmental, economic, financial and social dimensions. Working with both developed and developing countries, the OECD aims to ensure that all societies can harness the benefits of the ocean on a sustainable and inclusive basis. Find out more at www.oecd.org/ocean.

\section{The OECD Environment Policy Paper series}

Designed for a wide readership, the OECD Environment Policy Papers distil many of today's environment-related policy issues based on a wide range of OECD work. In the form of country case studies or thematic reviews across countries, the Papers highlight practical implementation experience.

\author{
Visit our websites \\ www.oecd.org/ocean \\ www.oecd.org/environment
}

Join the discussions on Twitter @OECD_ENV

\section{Contacts}

andrew.prag@oecd.org

kate.kooka@oecd.org

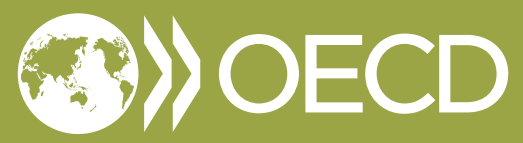

OECD Environment Directorate 